\title{
Prospective Science Teachers' Views related to the Turkish Education System: Current Problems and Proposed Solutions
}

\author{
M. Diyaddin YAŞAR ${ }^{a^{*}}$, Mustafa SÖZBiLíi ${ }^{b}$
}

${ }^{a}$ Harran Üniversitesi, Eğitim Fakültesi, Şanlıurfa/Türkiye

${ }^{\mathrm{b}}$ Atatürk Üniversitesi, Kazım Karabekir Eğitim Fakültesi, Erzurum/Türkiye

\section{Article Info}

DOI: 10.14812/cuefd.309455

Keywords:

Turkish education system,

Prospective science teachers,

Science education,

Problems,

Solution proposals.

\begin{abstract}
This study aims at identifying the current problems of the Turkish education system and developing probable solutions in the light of the opinions of prospective science teachers. This study is guided by qualitative descriptive methodology. The participations consists of 518 (336 female and 182 male) prospective science teachers at their final year (senior) in nine different universities during the 2013-2014 academic year. An opinion determination form comprised of open-ended questions is used as a data collection instrument. Study data are analyzed with content analysis as a type of qualitative analysis. The problems and proposed solutions found from the study are grouped under four main headings: structural-administrative problems $(32.18 \%)$ and solutions (32.54\%); teaching-learning problems $(35.18 \%)$ and solutions $(34.35 \%)$; problems related to teacher training $(23.84 \%)$ and solutions $(26.94 \%)$ and problems related to assessment $(8.8 \%)$ and solutions (6.17\%). As a conclusion, various proposals are made based on the research findings.
\end{abstract}

\section{Fen Bilgisi Öğretmen Adaylarının Türk Eğitim Sistemi'ne Yönelik Görüşleri: Güncel Sorunlar ve Çözüm Önerileri}

Makale Bilgisi

DOI: $10.14812 /$ cuefd. 309455

Anahtar Kelimeler:

Türk eğitim sistemi,

Fen bilgisi öğretmen adayları,

Fen eğitimi,

Problemler,

Çözüm önerileri.

\section{Öz}

Bu araştırmada, fen bilgisi öğretmen adaylarının görüşlerine göre, Türk eğitim sisteminin güncel sorunlarının tespit edilmesi ve bu sorunlara yönelik muhtemel çözüm önerilerinin geliştirilmesi amaçlanmıştır. Bu çalışma, nitel araştırma yaklaşımlarından biri olan betimsel yöntem ile yürütülmüştür. Araştırmanın çalışma grubunu, 2013-2014 eğitim-öğretim yılında dokuz farklı üniversitede öğrenim göre 518 (336 kız ve 182 erkek) son sınıf fen bilgisi öğretmenliği bölümü öğrencileri oluşturmaktadır. Veri toplama aracı olarak açık uçlu sorulardan oluşan görüş belirleme formu kullanılmıştır. Araştırmadan elde edilen verilerin, nitel analiz çeşitlerinden biri olan içerik analizi yapılmıştır. Elde edilen bulgulara göre eğitim sistemindeki sorunlar ve çözüm önerileri: yapısal-yönetimsel problemler (\% 32,18) ve çözüm önerileri (\% 32,54); öğrenmeöğretme süreci problemleri $(\% 35,18)$ ve çözüm önerileri $(\% 34,35)$; öğretmen eğitimi ile ilgili problemler $(\% 23,84)$ ve çözüm önerileri $(\% 26,94)$ ve ölçme-değerlendirme ile ilgili problemler $(\% 8,8)$ ve çözüm önerileri $(\% 6,17)$ olmak üzere dört kategori altında toplanmıştır. Daha sonra araştırma sonuçlarına dayalı olarak çeşitli öneriler sunulmuştur.

*Author: mdiyaddinyasar@harran.edu.tr 


\section{Introduction}

It is a fact that there is economic, social, political and environmental crisis and distress almost anywhere in the world. As one examines the existing problems in any country, it can be seen that these problems basically arise from deficiencies in basic education and shortcomings in the education system. The problems in the education system affect other areas directly. Also in Turkey it appears that there are certain problems waiting for solution for a long time, and it is known that the rapid development in science and technology, new requirements, globalization and so on cause the education system to be even more ineffective and unproductive (Gedikoğlu, 2005). In addition, the existing problems and shortcomings can be overcome by creating an effective, efficient and contemporary education system (Altan, 2014). In this regard, education is considered to be the most important element for a country. It has an important role in development of countries as well as cross-border competition. It is seen that world countries turn more to this area in search of solution to existing problems. To this end, various innovations, reformations and improvement works are carried out in education systems. As a developing country, Turkey is also monitoring such reform movements in order to keep up with the time and educate individuals that can act at the speed of advances in science and technology (Erginer, 2009). Therefore, serious structural and instructional changes are implemented in the Turkish education system from time to time. The changes in the education system have subsequently affected science education. Thus, there have been several improvements in science education at structural, educational and curricular level.

Turkey, with a population of approximately 77 million and seven geographical regions and 81 provinces, is a country that serves as a bridge between Asia and Europe. The Republic of Turkey was founded in 1923 after the collapse of the Ottoman Empire following World War II (Özden, 2007). Following the foundation of the new state in 1923, the Turkish education system began to be shaped, and it was realized that education plays the most important role which to helps a country catch the era, progress and develop and reach the level of contemporary civilizations (Grossman, Onkol and Sands, 2007). Then, various reforms were made in social life and particularly in education (Turkmen and Bonnstetter, 2007). In this direction, the Turkish education system was built on the reformations of Atatürk, the founder of the Republic of Turkey, after the Turkish Independence War (Sozbilir, Kutu and Yasar, 2012; Turkmen and Bonnstetter, 2007). In 1920, even before the Republic was proclaimed, Ministry of National Education (MoNE) was founded as a body responsible for organization, execution and supervision of educational services (Özyılmaz, 2013). Then, Law of Unification of Instruction was adopted in 1924 as the first reform movement in education, whereby the Turkish education system started to be formed (Barlas and Köksal, 2011; Özden, 2007).In accordance with the law, all schools except military schools were unified under the roof of the MoNE, leading to creation of the central management system in Turkish education up to date. Most reforms were introduced in both education system and social life such as adoption of the Latin alphabet as the official alphabet replacing the Arab alphabet in 1928 and adoption of secularism in education, social life and legal area (Türkmen and Bonnstetter, 2007). Today a number of regulatory, executive and supervisory education services are executed by the MoNE such as provision of primary, lower secondary, upper secondary education (high schools), opening of schools, appointment of teachers, preparation of curriculum and so on (Özyılmaz, 2013). In addition, the Higher Education Council (HEC) was established in 1981 in order to plan, organize, manage and supervise activities in universities as higher education institutions. Besides, the basic principles of the Turkish national education were adopted as generality and equality, individual and community needs, orientation, the right to education, equality of opportunities and possibilities, continuity, Ataturk's reforms and principles and Atatürk's nationalism, democracy education, secularism, science, planning, mixed-sex education and education everywhere (Şişman, 2012).

In the context of the Turkish education system, a number of innovations and improvements have also been realized in science education since 1924. The developments and changes in this area have often been affected from events and situations in Europe and the western world (Ayas, 2013; Çalık and Ayas, 2008). The first effect started in 1930s and lasted until 1940s. While it emerged in the US and spread across the whole Europe, it remained limited to the translation of mostly English textbooks into 
Turkish for science education in Turkey. Secondly, an effect wave became influential during the Second World War years between 1940 and 1960. Turkey experienced that wave in 1950s in the form of efforts to develop sample curricula. However, this second effect remained in a very narrow scope covering only a few schools. The third effect showed itself during the cold war between the years 1960 and 1985 after World War II. During that period, it was seen that there is much competition among world countries in many areas including education. This period was dominated by curriculum development activities in the US. In Turkey, attempts were made to adopt the US-origin modern science teaching curricula with the cooperation of Turkish and American educators, science high schools were opened as role models for other high schools, and modern science curricula were applied in these schools. Still, curriculum development efforts in science teaching studies failed to spread across the whole country due to the circumstances then surrounding the country and thus did not provide the desired success (Çalık and Ayas, 2008). The fourth influence originating from the West in science education and curriculum development activities entered Turkey after dissolution of the Soviet Union (Çalık and Ayas, 2008). Its effects were seen in our country in 2000 and beyond. The constructivist approach emerged in 1990s in the west, but it started to be apparent only after 2005 in primary school science curricula in Turkey. In this context, primary school (for 4. and 5. grades) and secondary school (for 6.,7.and 8.grades) science curricula was revised as Science and Technology curriculum in 2005 and 2006 and it was followed by high school science curricula after in 2007 (e.g. chemistry, physics and biology teaching) (MoNE, 2005; MoNE, 2006; MoNE, 2007). In these curricula, modern understandings of learning or modern learningteaching approaches/philosophy came to the fore such as constructivist approach, active learning, student centered learning and thematic approach as well as teaching sensitive to multiple intelligences theory and individual differences (Gömleksiz and Kan, 2007). But after a short time, after 2013, further changes were made on the education system in terms of structure and instruction. Consequently, the efforts to create actually modern curricula for primary, secondary and high school (physics, chemistry, biology, etc.) science curricula became outstanding in Turkey in 2005 and after 2013. The compulsory schooling period was increased to 12 years in the 2012-2013 academic years. In this scope, the primary, secondary and high school education was rearranged as $4+4+4$ years. In other words, primary school education was reduced from 5 to 4 years, while secondary school (first stage of secondary school education) increased from 3 to 4 years and high school education (second stage of secondary school education) from 3 to 4 years as well (Durmuş̧elebi and Bilgili, 2014). In addition, it was decided that children start school at the age of 66 months (5.5 years) in line with the request of parents. Currently, science education is started at the 3 rd grade in primary school and it continues as a separate science course starting from the 4 th grade until the end of the first stage of secondary school education (grade $3,4,5,6,7$, and 8) (MoNE, 2013). From the second stage of secondary education, science education is offered in three separate areas as physics, chemistry and biology (MoNE, 2013). In this case, a student who decides to study science at university receives education in science for about 13 years from the primary 3rd grade until the last year of higher education.

Education as stated in the preceding paragraph, also constitutes an important aspect of human life. The relevant literature provides both Turkish and international studies, though very limited, related to problems faced in the education system. For example; Ahmad, Rauf, Imdadullah and Zeb (2012), Memon (2007), Rashid and Mukhtar (2012) examine the problems in the education system in Pakistan. They found out a number of reasons for failure of the education system: the lack of continuity in education policies, constantly changing policies of education, corruption, the lack of adequate financial support, inadequate human resources training, the lack of vision holder leaders, political instability, insufficient infrastructure, inability to meet local needs and reality, and centralized management in education, and so on. Also, Boyer and Hamil (2008) found out in their study that the factors such as the professional deformation of teachers, insufficient school-family collaboration or insufficient involvement of parents in educational activities and deficiencies in reading abilities of students impede the progress of the US education system. Adeyinka (1975), Odia and Omofonmwan (2007), Udey, Ebuara, Ekpah and Edet (2009) carried out research on the problems in the Nigerian education system. They obtained an exhaustive list of problems such as administrative and supervisory issues, inability of the central government to meet local and regional needs, the existence of multiple educational system, constantly 
changing system of education and curricula, deficiencies related to the in-service training, lower education level of families, guidance issues and poverty, the lack of adequate financial support for education, infrastructural problems, physical incapacity and lack of teaching materials and so on. In another study carried out by Sutherland (1982), the development and problems of the education system in Northern Ireland between 1952 and 1982 were examined in reference to the literature. As for Turkey, research is carried out on problems and offered solutions in the education system, though not many. For example, Gedikoğlu (2005) found out in his study that the schooling rate is low at pre-school and higher education levels, sufficient budget is not allocated for education and there are issues almost at all levels of education. Moreover, it was revealed that the Turkish education system is not implemented effectively due to the problems related to the system, infrastructure and teaching-learning process (Durmuşçelebi and Bilgili, 2014) and central examinations, physical incapacity, overcrowded classrooms, rote learning, lack of teacher qualifications, political concerns, lack of financial resources, the problems caused by teachers' appointment, and other problems resulting from private courses or evening schools (Yılmaz and Altınkurt, 2011). Demirtaş, Üstüner and Özer (2007) investigated the problems faced in school administration. They found out various problems such as those related to teachers, school climate, students, school administration and school building. Another study is carried out by Cerit, Akgün, Yıldız and Soysal (2014) on the problems faced in the new Turkish education system put into effect during the 2012-2013 academic years. They noted several problems such as the early age at children start school, physical incapacity, the problems related to the teaching-learning process, education system and the structure, and school managements and staffs. Özyılmaz (2013) in his study listed the problems faced in the Turkish education system: ideological approach to education, inability to benefit sufficiently from educational experts, administrative problems in education, curriculum development, pupil personal services, the issue of contemporary inspection and auditing, the status of public and private schools in education, educational financing issues, teacher training and employment problems, transition to secondary and higher education, the problems of the levels of education, learning-teaching process, nationalization of education and so on. As a result, solutions were proposed for these problems.

Again in the context of Turkey as mentioned earlier, education in general and science education in particular cover a long period of time. Still, as Keser (2005) pointed out, though education systems, science teaching and science curricula are designed in consideration of the concept of the modern era, they prove ineffective in practice due to various reasons. These include inadequate preparation by teachers or incapacity of teachers, the use of ineffective learning-teaching techniques/methods and assessment methods, overcrowded classrooms and lack of teaching materials and so on. It is seen in both national and international studies that science teaching suffers from serious shortcomings in Turkey compared with other countries (Özden, 2007). It is also seen that, as stated earlier, studies which aim at identifying problems in the Turkish education system and science education and proposing solutions are not widespread. In our country, an individual needs to exert efforts for a long time in order to acquire a profession in science field and to be a teacher of science until the end of the tertiary education. In addition, as known, preservice teachers and in particular preservice science teachers stand as individuals who self-host the students' and future teachers' roles in the education system. Therefore, looking from the two different perspectives of the two different roles might produce more healthy and realistic assessment for both problems and solutions in the education system (Yeşil and Şahan; 2015). Bearing this in mind, we would like to know what prospective science teachers think about the education system in Turkey throughout this time. What kind of problems do they face? What needs to be done for better science education and implementation of the education system? This study is expected to bring considerable contribution to the literature as an attempt to answer these questions. This study is carried out with the intention of identifying the current problems of the Turkish educational system and offering solutions in the light of the prospective science teachers' views. It is aimed at shedding light onto the shortcomings of the education system as well as its consequences for science education, and developing solutions to overcome the current shortcomings. For the purpose stated above, the study is carried out with to search for answers to the following research questions: 
1- In the opinion of prospective science teachers, what are the current problems of the Turkish Education System?

2- In the opinion of prospective science teachers, what solutions could be proposed to the current problems of the Turkish Education System?

\section{Method}

This research was conducted with a descriptive methodology based on qualitative approach. Descriptive methodology can be carried out with a quantitative approach and with a qualitative approach as well. Qualitative approach is a research type which put forwards perceptions and events in the natural environment in a realistic and holistic manner by using instruments such as observation, interviews and document analysis (Yıldırım and Şimşek, 2008). In present study, qualitative approach was used since we aim at identifying the prospective science teachers' opinions in the natural and real environment. In line with this approach, the study was carried out as an attempt to describe the current situation related to the current problems of the Turkish education system and possible solutions according to the views of the students in the last year of primary science teacher training department

\section{Participants}

The research was carried out with 518 senior graders in science teaching department during 20132014 academic years. Study sample was selected by using convenience sampling method. Convenience sampling is used for the purpose of easy access to subjects, and access to suitable and eligible sample for research (McMillan and Schumacher, 2010). Also time, money and manpower requirements of this sampling method are relatively low (Büyüköztürk, Kılıç-Çakmak, Akgün, Karadeniz and Demirel, 2008). In this study, the participants were selected from nine different universities across five different geographical regions of Turkey. The students in science teacher training department were accessed via faculty members in those universities. 518 senior graders in those universities participated in the study on a voluntary basis.

Table 1. Demographic data about participants

\begin{tabular}{lcccccc} 
Region & $\begin{array}{c}\text { Eastern } \\
\text { Anatolia } \\
\text { Region }\end{array}$ & $\begin{array}{c}\text { Black Sea } \\
\text { Region }\end{array}$ & $\begin{array}{c}\text { Aegean } \\
\text { Region }\end{array}$ & $\begin{array}{c}\text { Mediterrane } \\
\text { an Region }\end{array}$ & $\begin{array}{c}\text { South-eastern } \\
\text { Anatolia } \\
\text { Region }\end{array}$ & $\begin{array}{c}\text { Total } \\
\text { Gender }\end{array}$ \\
\hline Female & 162 & 71 & 43 & 36 & 24 & 336 \\
Male & 113 & 33 & 15 & 14 & 7 & 182 \\
Total $(\mathbf{n})$ & & & & & & $\mathbf{5 1 8}$ \\
\hline
\end{tabular}

\section{Data Collection Procedure and Analysis}

For collecting data, an "Structured Opinion Form" was developed by researcher and to obtain written responses of the prospective science teachers. The form has two parts. In part one; there is a question to obtain views of interviewees related to the current problems of the Turkish education system. Part two consists of a question to find out interviewees' proposals for solution of the problems.

The written data obtained from prospective science teachers were analyzed by using content analysis as a variety of qualitative data analysis. Qualitative data analysis has three main stages as data display, summarizing and interpreting (Büyüköztürk et al. 2008). In the content analysis, the initial set of categories and codes direct the research, while the nuances, styles, imagery and meaning and others are identified during the analysis or study; however, in some cases the codes can be created at first and the categories can be determined (Yıldırım and Şimşek, 2008). Also in this study, the study data were read in-depth. Initially, the data collected from two different universities, approximately $10 \%$ of total data, were examined to put forward the current problems and proposed solutions in the context of the Turkish education system. Then, the analyzed data ( $10 \%$ of qualitative data) was reviewed and 
compared with the first analysis by researchers for consistency. Small amount of the disagreements were discussed between the authors and then the rest of the qualitative data were analyzed by the first author with the help and leadership of second author. In this way, the codes representing the problems in the Turkish education system and probable solutions were typed according to the participants' views. Next, the codes were examined to combine the similar ones under the same category resulting in four different categories. Analysis of the remaining data was examined in detail on the basis of the codes and categories available. In the case of different codes during the content analysis, additional codes were inserted under the appropriate category. Percentage and frequency of each code and category were calculated and displayed in tables.

\section{Result}

Analysis of the study data yielded a total of 2399 different problems and 2090 solutions by 518 prospective science teachers. More than one problem was mentioned by each participant and more than one solution was proposed for each problem referred. According to the study data, the problems and solutions related to the Turkish education system were discussed under four main section as structural-administrative problems $(f=772, \% 32.18)$ and solutions ( $f=680, \% 32.54)$; problems $(f=844$, $\% 35.18$ ) and solutions ( $f=718, \% 34.35$ ) related to learning-teaching process, problems ( $f=572, \% 23.84)$ and solutions $(f=563, \% 26.94)$ related to teacher training, lastly problems $(f=211, \% 8.8)$ and solutions $(f=129, \% 6.17)$ related to assessment issue. After, sub-codes were inserted appropriately under each category. Finally, the problems stated by participants were identified and solutions were proposed accordingly.

\section{Structural-Administrative Problems and Proposed Solutions}

This section provides structural-administrative problems of the education system (Table 2) and a variety of solutions to these problems (Table 3) from the prospective science teachers' point of view.

As it can be seen from Table 2, thirty-one codes were offered as for structural-administrative problems of the education system. The frequency ( $f$ ) and percentage (\%) of each of the referred codes were calculated and presented in Table 2. Of total 2399 problems indicated by participants, 772 of them were found related to structural-administrative problems, which holds $32.18 \%$ of all problems $(100 \times 772$ $=77200,77200 / 2399=32.18)$. In addition, the percentage of each code under this category was calculated out of 772 frequencies, and an example calculation was made with the percentage of the first code as $188 \times 100=18800$ and $18800 / 772=23.35$. The most frequently mentioned structuraladministrative problem was found as "constant change of the education system". It was the first code in the list with a share of $23.35 \%(\mathrm{f}=188)$. It was followed by other codes as following: "Inequality of opportunities and possibilities in education ( $f=75, \% 9.71)$ ", "Constant change of the administrative body in charge of the education system, and education being an object of political concerns ( $f=71, \% 9.19)$ ", "Lack of sufficient budget for education and lack of importance given to education ( $f=48, \% 6.21)$ " and "Inadequate functioning of the merits and supervision mechanism ( $f=43, \% 5.56)$ ".

Table 2. Structural-administrative problems

\begin{tabular}{|c|c|c|c|}
\hline & Problems (f=772, \%32.18) & $f$ & $\%$ \\
\hline Codes & $n=518, \sum f=2399$ & & \\
\hline P1 & Constant change of the education system & 188 & 23.35 \\
\hline P2 & Inequality of opportunities and possibilities in education & 75 & 9.71 \\
\hline P3 & $\begin{array}{l}\text { Constant change of the administrative body in charge of the education } \\
\text { system, and education being an object of political concerns }\end{array}$ & 71 & 9.19 \\
\hline P4 & $\begin{array}{l}\text { Lack of sufficient budget for education and lack of importance given to } \\
\text { education }\end{array}$ & 48 & 6.21 \\
\hline P5 & Inadequate functioning of the merits and supervision mechanism & 43 & 5.56 \\
\hline P6 & $\begin{array}{l}\text { Not involving administrators, teachers, students and parents in the } \\
\text { changing process of the education system and subsequent notice of the } \\
\text { changes to them. }\end{array}$ & 38 & 4.92 \\
\hline
\end{tabular}


M. Diyaddin YAŞAR, Mustafa SÖZBiLiR- Çukurova Üniversitesi Eğitim Fakültesi Dergisi, 46(1), 2017, 165-201

\begin{tabular}{|c|c|c|c|}
\hline Codes & Problems & $f$ & $\%$ \\
\hline P7 & Inability of parents to assume their roles satisfactorily in education & 31 & 4.01 \\
\hline P8 & $\begin{array}{l}\text { Inability of implementing a democratic, scientific, liberal, modern and } \\
\text { secular education system }\end{array}$ & 30 & 3.90 \\
\hline P9 & $\begin{array}{l}\text { Shortage of employment among graduates of university and thus their } \\
\text { tendency towards areas with abundant job opportunities }\end{array}$ & 25 & 3.23 \\
\hline P10 & $\begin{array}{l}\text { Increasing number of universities and decreased qualifications of } \\
\text { universities }\end{array}$ & 22 & 2.84 \\
\hline P11 & $\begin{array}{l}\text { Failure to put into practice the changes in the education system and } \\
\text { remaining in theoretical dimension }\end{array}$ & 21 & 2.72 \\
\hline P12 & $\begin{array}{l}\text { Direct adaptation of foreign educational systems that are not related } \\
\text { our cultural tissue }\end{array}$ & 21 & 2.72 \\
\hline P13 & $\begin{array}{l}\text { The lack of a multicultural education system; existing of an education } \\
\text { system that brings up uniform individuals (lack of education in the } \\
\text { mother tongue in different languages ...) }\end{array}$ & 18 & 2.33 \\
\hline P14 & Unsatisfactory and confusing course books prepared by the MoNE & 16 & 2.1 \\
\hline P15 & $\begin{array}{l}\text { Not giving enough importance to special education and ineffective } \\
\text { implementation of the integrated mainstreaming education }\end{array}$ & 15 & 1.94 \\
\hline P16 & Seeing education as a means of business and profit & 15 & 1.94 \\
\hline P17 & Sending children to school at an early age (66 months old) & 14 & 1.81 \\
\hline P18 & Paid education, partly though & 12 & 1.6 \\
\hline P19 & Heavily loaded content of curricula & 11 & 1.43 \\
\hline P20 & $\begin{array}{l}\text { The lack of communication and coordination between administrators, } \\
\text { teachers and students }\end{array}$ & 11 & 1.43 \\
\hline P21 & $\begin{array}{l}\text { Anti-socializing effect of the current education system on students } \\
\text { (bringing up individuals with lower self-esteem and who cannot express } \\
\text { themselves, etc.) }\end{array}$ & 10 & 1.30 \\
\hline P22 & Imposed, repressive and compulsory education & 7 & .90 \\
\hline P23 & $\begin{array}{l}\text { Inadequate basic education (existence of students that cannot read or } \\
\text { write yet) }\end{array}$ & 6 & .80 \\
\hline P24 & Inflexible science curricula that are not appropriate for students' level & 6 & .80 \\
\hline P25 & Inadequate weekly hours of science education & 5 & .65 \\
\hline P26 & Not giving enough importance to students and using them as subjects & 5 & .65 \\
\hline P27 & A centralized approach dominant in educational management & 4 & .51 \\
\hline P28 & The lack of adequate housing facilities and dormitories & 3 & .40 \\
\hline P29 & $\begin{array}{l}\text { The lack of adequate scholarship for students and repaid nature of } \\
\text { some of the scholarships awarded to students }\end{array}$ & 3 & 40 \\
\hline P30 & $\begin{array}{l}\text { Merely focusing on learning activities neglecting the dimension of } \\
\text { education }\end{array}$ & 3 & .40 \\
\hline P31 & Bringing up of consumer individuals by the education system & 2 & .25 \\
\hline Total & & 772 & 100 \\
\hline
\end{tabular}

P:Problem.

Probable solutions proposed by science teachers as a response to the structural and administrative problems are given in Table 3. As can be seen from Table 3, thirty-seven different codes were listed under this heading. The frequency (f) and percentage (\%) of each of the referred codes were calculated and presented in Table 3. Of total 2090 solutions proposed by participants, 680 were placed under the category of solutions for structural-administrative problems, which holds $32.54 \%$ of all solution proposals $(100 \times 680=68000,68000 / 2090=32.54)$. In addition, the percentage of each code under this category was calculated out of 680 frequencies, and an example calculation was made with the percentage of the first code as $134 \times 100=13400$ and $13400 / 680=19.70 \%$. Five proposals were noted as the most frequently mentioned codes in relation with structural-administrative problems. The solution 
proposals were listed in an order of decreasing frequency as following: "Infrastructure must be prepared and preliminary works must be done to arrange the education system in the line with the requirements and it should not be constantly changed" ( $f=134, \% 19.70)$, "In education equality of opportunities and possibilities needs to be ensured in different regions, provinces, districts and villages" ( $f=61, \% 8.97)$, "Education should not be an object of political concerns (It should become a state policy)" ( $f=45, \% 6.62$ ), "In education, the merit and supervisory mechanism must work effectively" ( $f=43, \%$ 6.32), and "Budget allocated for education must be increased and more importance must be attached to science education" ( $f=41, \%$ 6.03).

Table 3. Proposed Solutions for Structural-Administrative Problems

\begin{tabular}{|c|c|c|c|}
\hline & Proposed Solution $(f=680, \% 32.54)$ & $f$ & $\%$ \\
\hline Codes & $n=518, \sum f=2090$ & & \\
\hline S1 & $\begin{array}{l}\text { Infrastructure must be prepared and preliminary works must be done to } \\
\text { arrange the education system in line with the requirements and it should } \\
\text { not be constantly changed. }\end{array}$ & 134 & 19.70 \\
\hline $\mathrm{S} 2$ & $\begin{array}{l}\text { In education, equality of opportunities and possibilities needs to be } \\
\text { ensured in different regions, provinces, districts and villages. }\end{array}$ & 61 & 8.97 \\
\hline S3 & $\begin{array}{l}\text { Education should not be the object of political concerns (it should } \\
\text { become a state policy.). }\end{array}$ & 45 & 6.62 \\
\hline S4 & $\begin{array}{l}\text { In education, the merit and supervisory mechanism must work } \\
\text { effectively. }\end{array}$ & 43 & 6.32 \\
\hline S5 & $\begin{array}{l}\text { Budget allocation for education must be increased and more importance } \\
\text { must be attached to science education. }\end{array}$ & 41 & 6.03 \\
\hline S6 & $\begin{array}{l}\text { Educational administrators must be selected among educators and they } \\
\text { should not be selected randomly }\end{array}$ & 36 & 5.29 \\
\hline S7 & $\begin{array}{l}\text { The employment policy must be examined and students must be } \\
\text { accepted to universities in line with needs. }\end{array}$ & 31 & 4.56 \\
\hline S8 & $\begin{array}{l}\text { An education system must be built which is appropriate for the needs of } \\
\text { society, cultural structure and students' properties }\end{array}$ & 30 & 4.41 \\
\hline S9 & $\begin{array}{l}\text { A scientific, democratic, universal, secular and liberal education system } \\
\text { must be established. }\end{array}$ & 29 & 4.26 \\
\hline S10 & $\begin{array}{l}\text { Educational administrators, teachers, students, parents and large groups } \\
\text { of the society must be applied for their opinions related to structuring of } \\
\text { the education system. }\end{array}$ & 27 & 3.97 \\
\hline S11 & $\begin{array}{l}\text { The role of parents in education must be increased, and families should } \\
\text { be educated (school-family collaboration should become operational). }\end{array}$ & 27 & 3.97 \\
\hline S12 & $\begin{array}{l}\text { The community, administrators, teachers, parents and students need to } \\
\text { be informed about the new education system. }\end{array}$ & 19 & 2.70 \\
\hline S13 & $\begin{array}{l}\text { Individuals who are social, confident, enterprising and responsible must } \\
\text { be brought up by education system. }\end{array}$ & 18 & 2.65 \\
\hline S14 & $\begin{array}{l}\text { When configuring the educational systems and looking for solutions for } \\
\text { the problems, developed countries must be examined as models }\end{array}$ & 16 & 2.35 \\
\hline S15 & $\begin{array}{l}\text { Multicultural education must be available (Not uniform individuals must } \\
\text { be brought up; education in the mother tongue must be provided in } \\
\text { different languages.) }\end{array}$ & 16 & 2.35 \\
\hline S16 & $\begin{array}{l}\text { Course books prepared by MoNE must be clear enough and appropriate } \\
\text { for students' levels }\end{array}$ & 14 & 2.06 \\
\hline S17 & $\begin{array}{l}\text { Importance should be given to special education and it should be } \\
\text { disseminated. }\end{array}$ & 12 & 1.76 \\
\hline S18 & $\begin{array}{l}\text { Content of curricula must be simplified and made more flexible and } \\
\text { appropriate for students' levels. }\end{array}$ & 10 & 1.47 \\
\hline
\end{tabular}




\begin{tabular}{|c|c|c|c|}
\hline Codes & Proposed Solutions & f & $\%$ \\
\hline S19 & $\begin{array}{l}\text { Students should be awarded non-repayable scholarships, the } \\
\text { scholarships should be disseminated and amounts should be increased. }\end{array}$ & 9 & 1.32 \\
\hline S20 & Education and teaching activities must be carried out together. & 9 & 1.32 \\
\hline S21 & $\begin{array}{l}\text { Education must be free at all levels (There should not be private } \\
\text { elementary schools, secondary schools, colleges, etc...). }\end{array}$ & 7 & 1.03 \\
\hline S22 & $\begin{array}{l}\text { Administrators need to act in a conscientious, logical and scientific way } \\
\text { and produce solutions while taking decisions related to education }\end{array}$ & 6 & .88 \\
\hline S23 & $\begin{array}{l}\text { Children should not be sent to school at a very young age and they } \\
\text { should be provided with science education through games. }\end{array}$ & 5 & .74 \\
\hline S24 & Education must not be a means of business or profit any longer. & 5 & .74 \\
\hline S25 & There should not be compulsory uniforms in schools. & 5 & .74 \\
\hline S26 & $\begin{array}{l}\text { Importance should be given to basic education (Language teaching } \\
\text { should be good). }\end{array}$ & 4 & .59 \\
\hline S27 & $\begin{array}{l}\text { Both number and quality of dormitories and accommodation facilities } \\
\text { must be increased. }\end{array}$ & 3 & .44 \\
\hline S27 & $\begin{array}{l}\text { Bridges must be built between academicians, teachers and students and } \\
\text { they should be strengthened. }\end{array}$ & 3 & .44 \\
\hline S29 & In science education, weekly hours of courses must be increased. & 3 & .44 \\
\hline S30 & $\begin{array}{l}\text { The number of students in science faculties should be reduced so that } \\
\text { those faculties can fulfill their main function. }\end{array}$ & 2 & .29 \\
\hline S31 & Privatization must be made in education. & 2 & .29 \\
\hline S32 & $\begin{array}{l}\text { In education, the number of vocational schools should be increased and } \\
\text { consideration should be given to vocational training. }\end{array}$ & 2 & .29 \\
\hline S33 & Pre-school education must be compulsory. & 1 & .15 \\
\hline S34 & $\begin{array}{l}\text { School opening and closing dates must be planned according to regional } \\
\text { conditions. }\end{array}$ & 1 & 0.15 \\
\hline S35 & $\begin{array}{l}\text { Supplementary performance books should be prepared besides course } \\
\text { books. }\end{array}$ & 1 & .15 \\
\hline S36 & In education, there should not be compulsory courses at the university & 1 & .15 \\
\hline S37 & $\begin{array}{l}\text { There should be all-day education and should not be morning-afternoon } \\
\text { distinction }\end{array}$ & 1 & .15 \\
\hline Total & & 680 & 100 \\
\hline
\end{tabular}

S: Solution.

\section{Problems and Solutions related to Teaching-Learning Process}

In this section, educational problems (Table 4) and solutions (Table 5) related to the learningteaching process are presented on the basis of the participants' views.

As can be seen from Table 4, there were listed fifteen codes related to educational problems faced in teaching-learning process. The frequency ( $f$ ) and percentage (\%) of each of the referred codes were calculated and presented in Table 4. Of total 2399 problems indicated by participants, 844 were placed under the category of learning-teaching process, which holds $35.18 \%$ of all problems $(100 \times 844=84400$, $84400 / 2399=35.18$ ). It was noted as the category with the highest frequency. In addition, the percentage of each code in this category was calculated out of 844 frequencies, and percentage of the first code was calculated as $160 \times 100=16000$ and $16000 / 844=18.96$ as an example. Of all learning and teaching problems, it was found out that the highest frequency was noted under "Theoretical and rote learning-teaching activities in science education (dominance of the traditional approach...) and inability to ensure permanent learning" code at $18.96 \%(f=160)$. It is followed by other codes such as "Physical incapacity (instruments, equipment, materials, laboratory equipment, overcrowded classrooms, lack of suitable school and classroom conditions, etc...) in science education (f=146, \% 17.30)", "In science 
education, dominance of the teacher-centered teaching method and lecturing ( $f=122, \%$ 14.50)", "Realization of science education independently on interests, needs, expectations and skills of students ( $f=121, \% 14.34)$ ", and "Ignoring individual differences in science education ( $f=75, \% 8.89)$ ".

Table 4. Problems related to learning-teaching process

\begin{tabular}{|c|c|c|c|}
\hline & Problem ( $f=844, \%=35.18)$ & $f$ & $\%$ \\
\hline Codes & $n=518, \Sigma f=2399$ & & \\
\hline P1 & $\begin{array}{l}\text { Theoretical and rote learning- teaching activities in science education } \\
\text { (dominance of the traditional approach...) and inability to ensure } \\
\text { permanent learning }\end{array}$ & 160 & 18.96 \\
\hline $\mathrm{P} 2$ & $\begin{array}{l}\text { Physical incapacity (instruments, equipment, materials, laboratory } \\
\text { equipment, overcrowded classrooms, lack of suitable school and classroom } \\
\text { conditions, etc..) in science education }\end{array}$ & 146 & 17.30 \\
\hline P3 & $\begin{array}{l}\text { In science education, dominance of teacher-centered teaching method and } \\
\text { lecturing }\end{array}$ & 122 & 14.50 \\
\hline P4 & $\begin{array}{l}\text { Realization of science education independently on interests, needs, } \\
\text { expectations and skills of students }\end{array}$ & 121 & 14.34 \\
\hline P5 & Ignoring individual differences in science education & 75 & 8.89 \\
\hline P6 & $\begin{array}{l}\text { Inadequate practice-based learning-teaching activities in science education } \\
\text { (laboratory-assisted teaching, activities inside and outside classroom) }\end{array}$ & 67 & 7.94 \\
\hline P7 & $\begin{array}{l}\text { Inadequate counseling and guiding service for students and misleading of } \\
\text { students }\end{array}$ & 37 & 4.38 \\
\hline P8 & $\begin{array}{l}\text { Getting poor benefit from information -communication technologies, } \\
\text { audio-visual materials and equipment in science education }\end{array}$ & 22 & 2.61 \\
\hline P9 & $\begin{array}{l}\text { Inadequate involvement of in-class debate during science education } \\
\text { (underestimation of students' opinions and thoughts) }\end{array}$ & 18 & 2.13 \\
\hline P10 & $\begin{array}{l}\text { Inability to ensure higher-order thinking skills among students in science } \\
\text { education (research, questioning, analysis, synthesis, etc.) }\end{array}$ & 16 & 1.90 \\
\hline P11 & $\begin{array}{l}\text { The lack of communication between students and teachers and existence } \\
\text { of problems between them in science education }\end{array}$ & 16 & 1.90 \\
\hline P12 & $\begin{array}{l}\text { Failure to provide an adequate level of connection with real life in science } \\
\text { education }\end{array}$ & 14 & 1.66 \\
\hline P13 & $\begin{array}{l}\text { Inability to transfer adequate content knowledge in science education and } \\
\text { thus students' turning to private courses }\end{array}$ & 14 & 1.66 \\
\hline P14 & $\begin{array}{l}\text { Discrimination by teachers in science classes (teachers' attention on more } \\
\text { hardworking and successful students...) }\end{array}$ & 10 & 1.18 \\
\hline P15 & Inadequate level of learning by doing-living activities in science education & 6 & .71 \\
\hline Total & & 844 & 100 \\
\hline
\end{tabular}

P: Problem.

Table 5 demonstrates solutions proposed by prospective teachers related to learning- teaching process. As can be seen from Table 5, fifteen different codes were determined in relation with suggestions for teaching-learning process. The frequency ( $f$ ) and percentage (\%) of each of the referred codes were calculated and presented in Table 5. Of total 2090 solutions indicated by participants, 718 were placed under the category of learning-teaching process, which holds $34.35 \%$ of all proposals $(100 \times 718=71800,71800 / 2090=34.35)$. It was noted as the category with the highest frequency. In addition, the percentage of each code in this category was calculated out of 718 frequencies, and percentage of the first code was calculated as $131 \times 100=13100$ and $13100 / 718=18.25$ as an example. The solutions proposed by prospective teachers related to teaching-learning process were listed in a decreasing order of frequency as following: "Teaching must be realized in line with students' interests, needs, levels of education, expectations and capabilities in science education ( $f=131, \%=18.25)$ ", "Alternative student-centered approaches and methods should be used and expanded in science 
education ( $f=129, \% 17.97)$ ", "Physical conditions (laboratory supplies, materials, and class sizes, etc.) in science education should be improved ( $f=106, \%$ 14.76)", "Practical teaching activities in science education (laboratory-aided, learning activities inside and outside classroom, etc.)should be disseminated(f=84, \% 11.70)" , and "Information-communication technologies, visual aids and materials should be used in an effective way for science education ( $f=57, \% 7.93)$ ".

Table 5. Proposed Solutions for Learning and Teaching Process

\begin{tabular}{|c|c|c|c|}
\hline \multirow[b]{2}{*}{ Codes } & \multirow{2}{*}{$\begin{array}{l}\text { Proposed Solution }(f=718, \% 34.35) \\
n=518, \sum f=2090\end{array}$} & \multirow[t]{2}{*}{ f } & \multirow[t]{2}{*}{$\%$} \\
\hline & & & \\
\hline S1 & $\begin{array}{l}\text { Teaching must be realized in line with students' interests, needs, levels of } \\
\text { education, expectations and capabilities in science education }\end{array}$ & 131 & 18.25 \\
\hline $\mathrm{S} 2$ & $\begin{array}{l}\text { Alternative student-centered approaches and methods should be used and } \\
\text { expanded in science education }\end{array}$ & 129 & 17.97 \\
\hline S3 & $\begin{array}{l}\text { Physical conditions (laboratory supplies, materials, and class sizes, etc.) in } \\
\text { science education should be improved }\end{array}$ & 106 & 14.76 \\
\hline S4 & $\begin{array}{l}\text { Practical-teaching activities in science education (laboratory-aided, learning } \\
\text { activities inside and outside classroom, etc.) should be disseminated. }\end{array}$ & 84 & 11.70 \\
\hline S5 & $\begin{array}{l}\text { Information-communication technologies, visual aids and materials should } \\
\text { be used in an effective way for science education. }\end{array}$ & 57 & 7.93 \\
\hline S6 & Individual differences of learners should be considered in science education. & 44 & 6.13 \\
\hline S7 & Teaching of science should be linked with real life. & 28 & 3.90 \\
\hline S8 & $\begin{array}{l}\text { Counseling, guidance and leading in science education must be carried out } \\
\text { effectively. }\end{array}$ & 28 & 3.90 \\
\hline S9 & Learning by doing-living activities must be ensured in science education. & 26 & 3.62 \\
\hline S10 & $\begin{array}{l}\text { In science education, emphasis should be placed onto high-level mental } \\
\text { development of students (research, inquiry, and finding solutions to } \\
\text { problems etc...). }\end{array}$ & 26 & 3.62 \\
\hline S11 & $\begin{array}{l}\text { In science education, curriculum content should be reduced and in-depth, } \\
\text { meaningful and lasting learning must be ensured. }\end{array}$ & 19 & 2.65 \\
\hline S12 & $\begin{array}{l}\text { In science education, importance should be given to classroom discussions } \\
\text { and on students' views. }\end{array}$ & 18 & 2.51 \\
\hline S13 & $\begin{array}{l}\text { Effective teacher-student and student-student interaction must be used in } \\
\text { science education. }\end{array}$ & 17 & 2.37 \\
\hline S14 & $\begin{array}{l}\text { Teachers need to spend time with students not only inside but also outside } \\
\text { school. }\end{array}$ & 3 & .18 \\
\hline S15 & In science education, it must be essential to learn how to learn. & 2 & .28 \\
\hline Total & & 718 & 100 \\
\hline
\end{tabular}

S:Solution.

\section{Problems and Proposed Solutions related to Teacher Training}

This section provides the educational problems (Table 6) and solutions (Table 7) related to teacher training according to the participants' views.

Also can be seen in Table 6, twenty different codes were written for problems related to teacher training. The frequency (f) and percentage (\%) of each of the referred codes were calculated and presented in Table 6. Of total 2399 problems indicated by participants, 572 were placed under the category of teachers' training, which corresponds to $23,84 \%$ of all problems $(100 \times 572=57200$, $57200 / 2399=23.84)$. In addition, the percentage of each code in this category was calculated out of 572 frequencies, and percentage of the first code was calculated as $97 \times 100=9700$ and $9700 / 572=16.96$ as an example. Of all problems related to teacher training, it was found out that the highest frequency was noted under the code "Teaching by those who are not qualified as teachers and running of science classes by them (Paid teaching, graduate of science faculty, and other branches...)" at $16.96 \%$ ( $f=97$ ). It is followed by the other most frequently mentioned codes in a decreasing order: "Low quality of teacher 
training and education faculties ( $f=92, \% 16.08)$ ", "Inadequate content knowledge and training of teachers (inability to transfer sufficient knowledge, being not open to innovations, inability to use technology, etc.) ( $f=72, \%$ 12.59)", "Shortage of teachers for science education and appointment of a small number of teachers... ( $f=64, \%$ 11.19)" and "Appointment of teachers based on the ESPS (Examination of Selection of Public Staff) results, which does not reflect the reality ( $f=55, \% 9.62)$ ".

Table 6. Problems related to teacher training

\begin{tabular}{|c|c|c|c|}
\hline & Problem $(f=572, \% 23.84)$ & f & $\%$ \\
\hline Codes & $n=518, \sum f=2399$ & & \\
\hline P1 & $\begin{array}{l}\text { Teaching by those who are not qualified as teachers and running of science } \\
\text { classes by them (Paid teaching, graduate of science faculty, and other } \\
\text { branches...) }\end{array}$ & 97 & 16.96 \\
\hline P2 & Low quality of teacher training and education faculties... & 92 & 16.08 \\
\hline P3 & $\begin{array}{l}\text { Inadequate content knowledge and training of teachers (inability to } \\
\text { transfer sufficient knowledge, being not open to innovations, inability to } \\
\text { use technology, etc.) }\end{array}$ & 72 & 12.59 \\
\hline P4 & $\begin{array}{l}\text { Shortage of teachers for science education and appointment of a small } \\
\text { number of teachers }\end{array}$ & 64 & 11.19 \\
\hline P5 & $\begin{array}{l}\text { Appointment of teachers based on the ESPS (Examination of Selection of } \\
\text { Public Staff) results, which does not reflect the reality }\end{array}$ & 55 & 9.62 \\
\hline P6 & Ineffective senior (elder) teachers & 50 & 8.74 \\
\hline P7 & $\begin{array}{l}\text { Provision of teaching education for those outside education faculties and } \\
\text { ineffective subsequent teaching }\end{array}$ & 40 & 6.99 \\
\hline P8 & $\begin{array}{l}\text { Professional deformation and teachers' not showing due diligence to their } \\
\text { profession }\end{array}$ & 25 & 4.37 \\
\hline P9 & Lack of appointment of younger generation as teacher & 17 & 2.97 \\
\hline P10 & Financial and economic challenges of educators/teachers & 14 & 2.45 \\
\hline P11 & $\begin{array}{l}\text { Discrepancies between the teaching training received by teachers and } \\
\text { practicalities of the profession. }\end{array}$ & 13 & 2.27 \\
\hline P12 & $\begin{array}{l}\text { Inadequate hands-on training/activities in teacher training and pushing } \\
\text { offering of practical courses mostly in later years of tertiary education }\end{array}$ & 8 & 1.40 \\
\hline P13 & $\begin{array}{l}\text { Lowering of the reputation of the teaching profession and lack of the state } \\
\text { preservation over the profession }\end{array}$ & 7 & 1.22 \\
\hline P14 & $\begin{array}{l}\text { The elective courses not being able to be selected by students in teacher } \\
\text { training }\end{array}$ & 4 & .70 \\
\hline P15 & Inadequate in-service training courses and low quality of such courses & 4 & .70 \\
\hline P16 & Aligning faculties of sciences with education faculties in practice & 3 & .53 \\
\hline P17 & Limited and inadequate powers given to the teachers in education. & 3 & .53 \\
\hline P18 & Reappointment or relocation of teachers in mid-year & 2 & .35 \\
\hline P19 & Teachers attributing failure to students & 1 & .17 \\
\hline P20 & Abundance of non-area courses in teacher training & 1 & .17 \\
\hline Total & & 572 & 100 \\
\hline
\end{tabular}

P:Problem.

The solutions proposed by science teachers as a response to problems related to teacher training are displayed in Table 7. As can be seen from Table 7, twenty-three different codes were prepared. The frequency $(f)$ and percentage (\%) of each of the referred codes were calculated and presented in Table 7. Of total 2090 solutions proposed by participants, 563 were placed under the category of proposals related to teacher training, which holds $26.94 \%$ of all solution proposals (100x563 $=56300$, $56300 / 2090=26.94)$. In addition, the percentage of each code under this category was calculated out of 563 frequencies, and an example calculation was made with the percentage of the first code as 
$118 \times 100=11800$ and $11800 / 563=20.96$. The suggestions brought by participants to improve teacher training are listed below. Five of the solutions were listed as the most frequently mentioned codes. These were noted as "The quality of teacher training and education faculties need to be improved (Prerequisite conditions should be identified and students with low scores should not be accepted, number of students should be reduced, effective content knowledge education should be provided and education should be organized in line with new approaches, etc.) ( $f=118, \%=20.96)$ ", "Adequate number of science teachers must be appointed (paid teaching status should be abolished) ( $f=69, \%$ 12.26).", "Elder teachers who are not effective teachers should be retired (the retirement age should be lowered) ( $f=67, \% 11.90)$ ", "Way must be paved for young and dynamic science teachers or educators and they must be brought to the profession(f=51, \% 9.06)", and "The profession of teaching should be performed by educators (Formation education should be abolished, science faculty should fulfill its original function ( $f=41, \%$ 7.28)".

Table 7. Proposed Solutions for Problems related to Teacher Training

\begin{tabular}{|c|c|c|c|}
\hline \multirow{2}{*}{ Codes } & Proposed Solution ( $f=563, \%$ 26.94) & \multirow[t]{2}{*}{$f$} & \multirow[t]{2}{*}{$\%$} \\
\hline & $n=518, \sum f=2090$ & & \\
\hline S1 & $\begin{array}{l}\text { The quality of teacher training and education faculties need to be } \\
\text { improved (Pre-requisite conditions should be identified and students } \\
\text { with low scores should not be accepted, number of students should be } \\
\text { reduced, effective content knowledge education should be provided and } \\
\text { education should be organized in line with new approaches, etc.) }\end{array}$ & 118 & 20.96 \\
\hline $\mathrm{S} 2$ & $\begin{array}{l}\text { Adequate number of science teachers must be appointed (paid teaching } \\
\text { status should be abolished) }\end{array}$ & 69 & 12.26 \\
\hline S3 & $\begin{array}{l}\text { Elder teachers who are not effective teachers should be retired (the } \\
\text { retirement age should be lowered) }\end{array}$ & 67 & 11.90 \\
\hline S4 & $\begin{array}{l}\text { Way must be paved for young and dynamic science teachers or educators } \\
\text { and they must be brought to the profession }\end{array}$ & 51 & 9.06 \\
\hline S5 & $\begin{array}{l}\text { The profession of teaching should be performed by educators (Formation } \\
\text { education should be abolished, science faculty should fulfill its original } \\
\text { function) }\end{array}$ & 41 & 7.28 \\
\hline S6 & $\begin{array}{l}\text { Effective and efficient in-service training need to be run for teachers in } \\
\text { the context of science teaching. }\end{array}$ & 38 & 6.75 \\
\hline S7 & $\begin{array}{l}\text { The quality of teachers (content knowledge, teaching qualifications, etc.) } \\
\text { should also be considered for appointment of teachers. }\end{array}$ & 29 & 5.15 \\
\hline S8 & $\begin{array}{l}\text { Merits must be ensured in appointment of teachers, it must not be based } \\
\text { on ESPS (Examination of Selection of Public Staff)scores alone. }\end{array}$ & 29 & 5.15 \\
\hline S9 & $\begin{array}{l}\text { In science education, teachers must give the courses related to their } \\
\text { respective fields (Classroom teachers, physics, chemistry and biology } \\
\text { teachers should not run primary science classes). }\end{array}$ & 28 & 4.97 \\
\hline S10 & $\begin{array}{l}\text { Devoted ones who love enjoying should perform the profession of } \\
\text { teaching. }\end{array}$ & 21 & 3.73 \\
\hline S11 & $\begin{array}{l}\text { Education courses, teaching practices and training activities must be } \\
\text { made efficient and disseminated (should be extended to all years and } \\
\text { should start at earlier grades). }\end{array}$ & 15 & 2.66 \\
\hline S12 & $\begin{array}{l}\text { Both material and spiritual needs of educators must be met to improve } \\
\text { their welfare. }\end{array}$ & 14 & 2.49 \\
\hline S13 & $\begin{array}{l}\text { Teachers must be well-equipped and open to innovations and they must } \\
\text { constantly improve themselves. }\end{array}$ & 9 & 1.60 \\
\hline S14 & $\begin{array}{l}\text { The teaching profession must be promoted and brought to a respectable } \\
\text { place in society. }\end{array}$ & 8 & 1.42 \\
\hline S15 & Teacher qualifications must be checked and tested on an annual basis. & 7 & 1.24 \\
\hline
\end{tabular}


M. Diyaddin YAŞAR, Mustafa SÖzBiLiR- Çukurova Üniversitesi Eğitim Fakültesi Dergisi, 46(1), 2017, 165-201

\begin{tabular}{|c|c|c|c|}
\hline Codes & Proposed solutions & f & $\%$ \\
\hline S16 & Powers and rights of teachers must be increased in education. & 4 & .71 \\
\hline S17 & $\begin{array}{l}\text { Link must be established between the training offered for prospective } \\
\text { teachers at university and practicalities in the real career. }\end{array}$ & 4 & .71 \\
\hline S18 & $\begin{array}{l}\text { Prospective teachers must be paid for practical lessons they run and the } \\
\text { teaching profession must be promoted. }\end{array}$ & 3 & .53 \\
\hline S19 & $\begin{array}{l}\text { Teachers need to work in coordination and cooperation with other } \\
\text { teachers. }\end{array}$ & 2 & .36 \\
\hline S20 & $\begin{array}{l}\text { Elective courses in the faculties of education must be selected by } \\
\text { students. }\end{array}$ & 2 & .36 \\
\hline $\mathrm{S} 21$ & Science teachers need to be trained according to the curricula developed. & 2 & .36 \\
\hline $\mathrm{S} 22$ & Teachers should not be relocated or reappointed frequently in mid-year. & 1 & .18 \\
\hline S23 & $\begin{array}{l}\text { Those who are not able to perform the teaching profession must be } \\
\text { transferred to another profession. }\end{array}$ & 1 & .18 \\
\hline Total & & 563 & 100 \\
\hline
\end{tabular}

S:Solution.

\section{Problems and Proposed solution related to Assessment}

This section provides the educational problems (Table 8) and solutions (Table 9) related to assessment issue from the prospective teachers' point of view.

Also can be seen in Table 8, seven different codes were determined for problems related to assessment process. The frequency $(f)$ and percentage $(\%)$ of each of the referred codes were calculated and presented in Table 8. Of total 2399 problems, 211 were placed under the category of assessment, which corresponds to $8,8 \%$ of all problems $(100 \times 211=21100,21100 / 2399=8.8)$. In addition, the percentage of each code in this category was calculated out of 211 frequencies, and percentage of the first code was calculated as $157 \times 100=15700$ and $15700 / 211=74.40$ as an example. Among the problems related to assessment, the code with the highest frequency of report was "Science education is examoriented and it continuously changes (at primary-secondary-high school and university level)" at $74.40 \%$ $(\mathrm{f}=157)$. It is followed by the other codes in a decreasing order of frequency as follows: "In science education, competitive-oriented evaluation is dominant ( $f=27, \% 12.79)$ ", "Using the passing grade as a threat against students ( $f=11, \%$ 5.21)", "Assessment not fulfilling its original function... ( $f=8, \% 3.79)$ " and "Ignoring the development of students in assessment process ( $f=3, \% 1.43)$ ".

Table 8. Problems related to assessment

\begin{tabular}{|c|c|c|c|}
\hline Codes & $\begin{array}{c}\text { Problem }(f=211, \% 8.8) \\
n=518, \sum f=2399\end{array}$ & $f$ & $\%$ \\
\hline P1 & $\begin{array}{l}\text { Science education is exam-oriented and it continuously changes (at } \\
\text { primary-secondary-high school and university level) }\end{array}$ & 157 & 74.40 \\
\hline $\mathrm{P} 2$ & In science education, competitive-oriented evaluation is dominant & 27 & 12.79 \\
\hline P3 & Using the passing grade as a threat against students & 11 & 5.21 \\
\hline P4 & Assessment not fulfilling its original function & 8 & 3.79 \\
\hline P5 & Ignoring the development of students in assessment process & 3 & 1.43 \\
\hline P6 & Insufficient capacity of assessment in determining the levels of students & 3 & 1.43 \\
\hline P7 & Implementation of the conditional passing system in some universities & 2 & .95 \\
\hline Total & & 211 & 100 \\
\hline
\end{tabular}

P:Problem.

The solutions proposed by science teachers as a response to problems related to assessment are given in Table 9. As can be seen from the table, nine codes were created. The frequency ( $f$ ) and percentage (\%) of each of the referred codes were calculated and presented in Table 9. Of total 2090 solutions proposed by participants, 129 were placed under the category of proposals related to 
assessment, which holds $6,17 \%$ of the proposals $(100 \times 129=12900,12900 / 2090=6.17)$. In addition, the percentage of each code under this category was calculated out of 129 frequencies, and an example calculation was made with the percentage of the first code as $47 \times 100=4700$ and $4700 / 129=36.43$. The proposals brought by participants to improve assessment in education were listed in the table 9 . Five of them with the highest level of frequency were as follows: "Development of students should also be taken into consideration in assessment of science education (activity-based, skills-oriented, process-oriented assessment should be at the forefront) ( $f=47 \%=36.43)$ ", "The weight of exams in both education and science education should be reduced. ( $f=40,31.00 \%)$ ", "The tests (National examinations) given across the whole country (primary, secondary, high school and college entrance exams and so on) should be systematic, standard and objective, they must not be constantly altered. (f=28, 21.71\%)", "Assessment based on cooperation should be expanded instead of competitive assessment ( $f=6,4.65 \%)$ ", and "In education context, grades should not be used as a threat $(f=3, \% 2.33)$."

Table 9. Proposed Solutions for Problems related to Assessment

\begin{tabular}{|c|c|c|c|}
\hline & Proposed Solution ( $f=129, \% 6.17$ ) & $\mathbf{f}$ & $\%$ \\
\hline Codes & $n=518, \sum f=2090$ & & \\
\hline S1 & $\begin{array}{l}\text { Development of students should also be taken into consideration in } \\
\text { assessment of science education (activity-based, skills-oriented, process- } \\
\text { oriented assessment should be at the forefront) }\end{array}$ & 47 & 36.43 \\
\hline $\mathrm{S} 2$ & $\begin{array}{l}\text { The weight of exams in both education and science education should be } \\
\text { reduced. }\end{array}$ & 40 & 31.00 \\
\hline S3 & $\begin{array}{l}\text { The tests (National examinations) given across the whole country (primary, } \\
\text { secondary, high school and college entrance exams and so on) should be } \\
\text { systematic, standard and objective, they must not be constantly altered. }\end{array}$ & 28 & 21.71 \\
\hline S4 & $\begin{array}{l}\text { Assessment based on cooperation should be expanded instead of } \\
\text { competitive assessment. }\end{array}$ & 6 & 4.65 \\
\hline S5 & In education context, grades should not be used as a threat. & 3 & 2.33 \\
\hline S6 & $\begin{array}{l}\text { In education context, assessment must have implications and impositions, } \\
\text { even grade repetition should be imposed if necessary }\end{array}$ & 2 & 1.55 \\
\hline S7 & $\begin{array}{l}\text { In assessment, association with everyday life should be brought to the fore } \\
\text { front. }\end{array}$ & 1 & .78 \\
\hline S8 & Conditional passing should be abolished at university. & 1 & .78 \\
\hline S9 & Passing grades should not be so high at universities. & 1 & .78 \\
\hline Total & & 129 & 100 \\
\hline
\end{tabular}

\section{Discussion \& Conclusion}

The results of the study indicated various problems in the Turkish education system from the perspective of prospective science teachers. In the scope of structural-administrative problems, frequent change of the overall education system and its components and exposure of education to current political developments are seen as the most frequently cited ones. As Özyılmaz (2013) points out, the dominance of ideological approaches in education constitutes the fundamental problem of the education system, and the communities acting with ideological motivations remain less developed, while those acting on real-political motivations achieve better results. In Turkey as well, education is one of the area most intensively facing ideological approaches (Özyılmaz, 2013). Also present study offers a distinct finding. According to the participants, involvement of educational administrators, teachers, parents and students is denied while changes are introduced to the education system, which is also a problem. Other problems indicated in the study include dominance of the central management understanding in education, inadequate announcement and publicity of the changes in the education system for the community, teachers, families and students. Also lack of sufficient budget allocation and resources for education seems to be another problem in this context. As another remarkable finding, the fact that educational administrators or decision-makers are not graduates of education faculty 
affects adversely our education system. It was found out that the inequality of opportunities and possibilities in different regions, provinces, districts and villages as well as challenges faced in bussed education seem to be hindering effective implementation of the education system in Turkey. Also participants often reported that the education system is configured regardless of the cultural structure of the society and the needs of the individuals, and employment policies are not much reflected in education. The findings of present study seem to support the findings reported by Kösterioğlu and Bayar (2014), Özyılmaz (2013) and Uygun (2013). Some problems were previously noted related to the Turkish education system by those studies: ideological motivations in education and dominance of politics in that area, a strict centralization management approach in education, poor use of educational sciences and educational researchers, inability to nationalize our education system, failure to provide systematic curriculum development, the lack of the contemporary inspection and supervision approach, pending financing problems in education, and unclear status of the public and private sectors in education context. In the end of our study, prospective science teachers offered a number of solutions to the structural-administrative problems of the education system. Particular emphasis was placed on providing an educational infrastructure and preparation so that changes could be applied as needed, and changes should not be made so often. It was concluded that the frequent changes in the education system lead difficulties of adapting to both students and parents. Indeed, education is a long-termed and laborious process and it has lasting outcomes. Also it was emphasized that surrounding conditions and physical possibilities in classrooms should be improved, and adequate number of teachers should be available across the whole country, and equality of opportunity and possibility should be provided for effective implementation of education. They also suggested that education must be turned into a state policy, and an effective mechanism of merits and supervision must be enabled for smooth functioning of the education system. Apart from these, it was highlighted that the budget allocation for education must be increased with an equitable distribution (Özyılmaz, 2013) and the growing emphasis on this area will bring positive outcomes to both education and other areas. Also Özyılmaz (2013) points out that it is needed to adopt the basic rules and approaches to universal educational sciences, recover the society, people and education system from the effect of ideology, and to benefit from any information and document that is freer. Contemporary conditions require individuals who are enterprising, responsible, productive and constantly renewing themselves, and the belief that the centralized management should be replaced with local and decentralized management is becoming widespread (Altan, 2014; Özyılmaz, 2013). It seems necessary to plan, organize and modify educational systems in accordance with contemporary conditions. This in turn will lead to emerging of a better and politically unbiased education system with higher qualifications.

Prospective science teachers also indicated a number of problems related to the teaching-learning process. As the most remarkable ones, they pointed out that rote theoretical learning still persists in the education system and science education and physical conditions in education environment are inadequate including instruments, materials and equipment. They also referred to the teacher-centered understanding/approaches in overall education and science education and ignoring the students' skills, needs and expectations in the context of education. Another result of this study is that individual differences of learners are not taken into account. Then, weight must be given to laboratory work, activities inside and outside classroom, learning by doing and experiencing, and learning-teaching associated with the real life by nature of science and science teaching; however, it could not be attained in the process of learning and teaching. Our findings seem in parallel with the findings obtained in Özyılmaz (2013). In this framework; teacher is positioned in the center of teaching-learning activities where students remain with a passive role and the understanding of rote theoretical learning still continues. This in turn hinders developing of student skills such as critical thinking, questioning, analyzing-synthesizing, producing, using the information and generating solutions to problems (Özyılmaz, 2013). According to the prospective science teachers' views, weight should be given to hands-on activities and laboratory studies as well as interests, needs and expectations of students for successful implementation of the overall education system and science teaching. Besides, it was suggested that emphasis should be placed on student-centered, alternative teaching-learning approaches and methods, improvement of physical conditions with equipment and materials, and 
effective and efficient use of information-communication technology to make contributions to the education system and science education. These results also seem to be in parallel with findings of Özyılmaz (2013); in the study, emphasis is placed on the need to use contemporary and studentcentered teaching-learning approaches, to ensure learning which is technology-supported learning and in conjunction with the immediate environment, taking into consideration of students' interests, abilities and needs, bring up individuals who are responsible for learning and sustain education in connection with the real life. Our findings also seem to be supportive of findings noted by Özden (2007) in that classrooms are overcrowded, there are poor physical conditions besides inadequate equipment and materials, and laboratory facilities are not used much in the context of science education. In the 21st century, education system is expected to equip students with not only parts of their national cultural heritage required by their time but also the information in their age; and mental, individual and social skills that shed light onto their future while helping their development (Özyılmaz, 2013). In addition, today schools have goals such as learning to learn; questioning, critically and creatively thinking; multiculturalism and multilingualism; problem solving, diversity of life styles and life-long learning (Özyılmaz, 2013). It was concluded that Turkish education system and learning-teaching process need to be directed towards such targets.

According to the prospective science teachers, there are also a number of problems arising from teacher training. Particularly, it was concluded that unqualified people are employed in paid teaching or temporary teaching such as graduates of science faculties as well as other faculties, which introduces negative consequences for the education system. In addition, the fact that higher quality education is not carried out in faculties of education and science education faculties was brought to light in this study. As an example, students are accepted to the faculty of education despite having with very low scores of success, a lot of students are accepted into these faculties, teacher-centered teaching-learning activities are predominant, practical works are inadequate, and so on. Moreover, it was found out that the teachers are not well trained and they are short of content knowledge and they fail to show dedication to the profession. Besides, it was noted that the problem becomes even more profound due to the lack of adequate in-service courses organized to promote the use of information and communication technologies and new approaches for all teachers. In addition, the prospective science teachers noted that recently education with lower quality is given to graduates of faculties of science and letters as well as other faculties in a very short period of time and they can teach after obtaining a certificate for teaching. The findings of this study seem in parallel with the findings by Kösterlioğlu and Bayar (2014), which point out that there are several issues related to teacher training and in-service training. Furthermore, the study seems similar to Özden (2007) in terms of results as it suggests that science teachers are not provided adequate in-service courses about the science curricula developed. Based on the data obtained from this study, several solutions were proposed by prospective science teachers in relation with teacher training. It was seen that particular emphasis is placed onto the need of restructuring the teacher training as well education faculties, accepting of qualified students to these faculties, determination of a number of prerequisite conditions, focusing student-centered teachinglearning and education activities based on the practical and new approaches and so on. They also noted that a sufficient number of teachers must be employed by government, and education should not be carried out in the form of paid teaching or temporary education. Moreover, it was pointed out that senior teachers who do not stop teaching due to their economic concerns should be retired. In this regard, economic and spiritual problems of both in-service and retired teachers need to be eliminated and their welfare must be increased. In this way, the way can be paved for young and energetic teachers by benefiting from valuable experience of elder teachers. Another thing stressed by participants was that effective, efficient and practical in-service courses should be offered to teachers who are currently employed to support their development. The findings from this study seem to support the findings of Özyılmaz (2013). This study listed a number of problems in teacher training and a variety of solutions for these issues; it pointed out that teacher training and subsequent employment opportunities are not well planned; as a solution, students can be accepted to schools and faculties according to the needs in every field; teaching is not merely about transferring one's knowledge to others, rather it is a matter of art and personality; high schools also suffer from poor curricula although they are the institutions 
responsible for educating students for higher education; in such schools Anatolian high schools, vocational high schools, teacher high schools, etc., curricula, teaching methods and techniques and education materials and equipment need revising in accordance with contemporary needs; as the teaching profession seems to be gradually losing its social prestige and significant improvement are needed for employee rights of teachers in order to make the profession more attractive socioeconomically; education faculties must be the only place for bringing up teachers and the programs in those faculties need to be revised in accordance with the era and effective in-service training courses must be offered to teachers (Özyılmaz, 2013).

Lastly, prospective science teachers addressed a number of problems related to assessment in education. In this context, they highlighted that there is an exam-oriented assessment system, it is constantly changing and student development is not taken into consideration in the context of assessment. Also as noted by Özyılmaz (2013), our education system is based on measuring the portion of knowledge remembered by students. Student success seems to be dependent on high scores obtained in exams. As a result, learners get away from social life who are incapable of inquiring, researching and offering solutions for problems. As another area of improvement, the participants pointed out that the weight of exams in education should be reduced, and measurement and evaluation based on student development and progress should be promoted instead. In this way, assessment based on cooperation rather than competition could lead to better implementation and progress of the education system and science education. As Özyllmaz (2013) also states that focus should be on not only learning outcomes but also student progress observed throughout the learning process, and measurement and evaluation should be conducted through hands-on activities that are related to knowledge and skills of students employed during learning. Lastly, as Altan (2014) states, the examoriented approach in education seems to be blocking the entrepreneurship potential of students. In the light of the foregoing, measurement and evaluation in Turkey should be structured in accordance with the contemporary requirements and appropriate conditions should be provided. 


\section{Türkçe Sürümü}

\section{Giriş}

Dünyanın hemen her yerinde ekonomik, sosyal, politik ve çevresel krizlerin ve sıkıntıların olduğu bir gerçektir. Bir ülkedeki mevcut problemler incelendiğinde temelde eğitimden ve eğitim sistemindeki aksaklıklardan kaynaklandığı görülmektedir. Eğitim sistemindeki problemler de direkt olarak diğer alanları etkilemektedir. Türkiye'de de öteden beri var olan ve çözülmesi gereken bir takım sorunların olduğu görülmekte ve bilim teknolojideki hızlı gelişim, yeni gereksinimler, küreselleşme vb. faktörlerin eğitim sistemini daha da etkisiz ve verimsiz hale getirdiği bilinmektedir (Gedikoğlu, 2005). Buna ek olarak, mevcut sorunlardan, krizlerden ve sıkıntılardan kurtulmanın yolu da yine etkili, verimli ve çağa uygun olarak düzenlenen eğitim sistemlerinin oluşturulmasına bağlıdır (Altan, 2014). Bu bakımdan, eğitim, bir ülke için en önemli unsurdur. Ülkelerin gelişmesinde ve ülkelerarası rekabette önemli bir role sahiptir. Dünyadaki ülkelerin de bu alana daha fazla yöneldikleri ve mevcut sorunlarına çözüm arama içerisinde oldukları görülmektedir. Bu bakımdan eğitim sistemlerinde çeşitli yenilikler, reformlar ve iyileştirme çalışmaları yapmaktadırlar. Türkiye de gelişmekte olan ülkeler arasında yer almakta ve çağı yakalamak, gelişen bilim ve teknolojinin hızına davranış olarak uyum sağlayabilecek bireyler yetiştirmek için bu reform hareketlerini izlemektedir (Erginer, 2009). Bunun sonucu olarak, Türkiye'de eğitim sistemi ile ilgili zaman zaman gerek yapısal olarak gerekse öğretim programlarında ciddi değişiklerin yapıldığı bilinmektedir. Eğitim sistemindeki değişikler akabinde fen eğitimine de etki etmiş, fen eğitiminde de hem yapısal hem de öğretim programlarında çeşitli iyileştirme çalışmaları yaşanmıştır.

Türkiye, yaklaşık olarak 77 milyon nüfusa sahip, 7 coğrafi bölge ve 81 ili olan, Asya ile Avrupa arasında köprü görevi gören bir ülkedir. Türkiye Cumhuriyeti, Birinci Dünya Savaşı sonrası Osmanlı İmparatorluğu'nun yıkılmasından sonra, 1923 yılında kurulmuştur (Özden, 2007). Yeni ülkenin 1923 yılında kurulmasından sonra Türk Eğitim Sistemi şekillenmeye başlamış ve çağı yakalayan, ilerleyen ve gelişen bir ülke olabilmek, çağdaş uyarlık düzeyine ulaşmak için, en önemli faktörün eğitim olduğu görülmüştür (Grossman, Onkol, Sands, 2007). Sosyal yaşamda ve özellikle eğitimde çeşitli reformlar yapılmıştır (Turkmen ve Bonnstetter, 2007). Türk eğitim sistemi de, Türk Kurtuluş Savaş'ından sonra Atatürk'ün, Türkiye Cumhuriyeti'nin kurucusu, reformlarına dayandırılmıştır (Sozbilir, Kutu ve Yasar, 2012; Turkmen ve Bonnstetter, 2007). Ülkede, Cumhuriyet daha ilan edilmeden önce 1920 yılında, Milli Eğitim Bakanlığı (MEB) kurulmuş ve eğitim hizmetlerinin düzenlenmesinden, yürütülmesinden ve denetlenmesinden sorumlu olmuştur (Özyılmaz, 2013). Daha sonra, eğitimdeki ilk reform hareketi olan 1924 yılında 'Tehvhid'i Tedrisat Kanunu'nun kabul edilmesi ile Türk Eğitim Sistemi oluşmaya başlamıştır (Barlas ve Köksal, 2011; Özden, 2007). Böylece, askeri okullar dışında tüm okullar tek bir çatı altında MEB'e bağlanmış ve günümüze kadar Türkiye'de eğitim sisteminde merkezi yönetim anlayışının oluşmasına yol açmıştır. Arap alfabesi yerine 1928 yılında Latin alfabesinin resmi olarak kullanılması ve eğitimde, sosyal yaşamda ve legal alanda laikliğin kabul edilmesi gibi eğitim sisteminde ve sosyal yaşamda pek çok reformlar yapılmıştır (Türkmen ve Bonnstetter, 2007). Günümüzde de ilköğretim, ortaöğretim birinci, ortaöğretim ikinci kademe yani lisedeki eğitim-öğretim hizmetleri; okulların açılması, öğretmenlerin atanması, öğretim programlarının hazırlanması vb. çeşitli düzenleme, yürütme ve denetleme vb. çeşitli eğitim hizmetleri, MEB’e bağlı olarak yürütülmektedir (Özyılmaz, 2013). Üniversitelerin yani yükseköğretim kurumlarının öğretimini planlamak, düzenlemek, yönetmek ve denetlemek amacıyla da 1981 yılında Yüksek Öğretim Kurumu (YÖK) kurulmuştur. Ayrıca, Türk milli eğitiminin temel ilkeleri: genellik ve eşitlik, ferdin ve toplumun ihtiyaçları, yöneltme, eğitim hakkı, fırsat ve imkân eşitliği, süreklilik, Atatürk inkılap ve ilkeleri ve Atatürk milliyetçiliği, demokrasi eğitimi, laiklik, bilimsellik, planlılık, karma eğitim, her yerde eğitim olarak benimsenmiştir (Şişman, 2012).

Türk eğitim sisteminin oluşmasıyla birlikte fen eğitiminde de 1924 yılından beri çeşitli yenilikler ve gelişmeler kaydedilmiştir. Bu alandaki gelişmeler ve değişimler genellikle Avrupa ve batı dünyasındaki olay ve durumlardan etkilenmiştir (Ayas, 2013; Çalık ve Ayas, 2008). Birinci etki, 1932'lerde başlayıp 
1940'lara kadar sürmüştür. Bu etki ABD'de başlayıp sonra Avrupa'yı içine almış, ülkemizde ise sadece ve çoğunlukla İngilizce fen eğitimindeki ders kitaplarının tercüme edilmesiyle sınırlı kalmıştır. İkinci etki, İkinci Dünya savaşı sırası 1940-1960 yıllarını kapsamıştır. Ülkemize yansımaları ise 1950'li yıllarda olmuş ve örnek program geliştirme çabaları olarak kabul edilmiştir. Ancak bu ikinci etki de çok dar bir kapsamlı olup sadece birkaç okulla sınırlı kalmıştır. Üçüncü etki, İkinci Dünya savaşı sonrası 1960-1985 yılları arası soğuk savaş döneminde kendini göstermiş ve dünya ülkeleri arasında eğitim dâhil birçok rekabetin olduğu görülmüştür. Bu döneme de ABD'deki program geliştirme çalışmaları hâkim olmuştur. Ülkemizde ise Türk ve Amerikan eğitimcilerinin işbirliği ile ABD kaynaklı modern fen öğretim programlarının adaptasyonu sağlanmaya çalışılmış ve diğer liselere kaynaklık yapması açısından fen liseleri açılmış ve bu okullarda modern fen programları uygulanmıştır. Ancak, bu dönemdeki fen alanındaki program geliştirme çalışmaları da ülkenin koşullarına bağlı olarak tüm ülke geneline yayılamamış ve istenen başarı sağlanamamıştır (Çalıkı ve Ayas, 2008). Türkiye'de fen eğitimi ve program geliştirme çalışmalarında batıdan gelen dördüncü etki Sovyetler birliğinin dağılmasıyla başlamıştır (Çalık ve Ayas, 2008). Ülkemizdeki etkileri ise 2000 yılı ve sonrasında görülmüştür. Batıda 1990'lı yılarda başlayan yapılandırmacı akımının etkisi ise ülkemizde 2005 yılından itibaren ilköğretim fen öğretim programlarında kendini göstermeye başlamıştır. Böylece, ilköğretim (4.ve 5.sınıflar) ve ortaöğretim (6,7.ve 8.sınıflar) ve fen öğretim programları 2005 ve 2006 yılından itibaren Fen ve Teknoloji Öğretim programı olarak değiştirilmiş ve bunu 2007 yılından itibaren liselerdeki fen öğretim programları (kimya, fizik ve biyoloji öğretim programları) izlemiştir (MEB, 2005; MEB, 2006; MEB, 2007). Geliştirilen bu programlarda, yapılandırmacı yaklaşım, aktiflik, öğrenci merkezlilik ve tematik yaklaşımın yanı sıra çoklu zekâ kuramı ve bireysel farklılıklara duyarlı öğretim gibi modern öğrenme anlayışları ön plana çıkmıştır (Gömleksiz ve Kan, 2007). Ancak kısa bir süre sonra 2013 yılından itibaren, eğitim sisteminde gerek yapısal olarak gerekse öğretim programlarında yine birtakım değişikliklere gidilmiştir. Bunun sonucu olarak, Türkiye'de 2005 ve daha sonra 2013 yıllarından itibaren ilköğretim, orta ve lise (fizik kimya biyoloji vb.) öğretim programlarında gerçek manada modern öğretim programlarını oluşturma çabaları göze çarpmaktadır. Ayrıca, Türkiye'de okul sistemi yapısı da, 2012-2013 eğitim-öğretim yılından itibaren zorunlu olmak kaydıyla 12 yıla çıkarılmış ve ilköğretim beş yıldan 4 yıla, ortaöğretim (ortaöğretim birinci kademe) üç yıldan 4 yıla, lise ise (ortaöğretim ikinci kademe) üç yıldan 4 yıla (yani 4+4+4) olacak şekilde düzenlenmiştir (Durmuşçelebi ve Bilgili, 2014). Ayrıca çocukların okula başlama yaşı da ailelerin isteğine bağlı olarak 66 ay yani (5,5 yı) olarak belirlemiştir. Fen eğitimi de, ilköğretim 3.sınıftan itibaren başlamakta ve 4.sınıftan itibaren ise ayrı bir fen bilgisi (3.4.5.6.7.8.sınıflar) dersi olarak ortaöğretim birinci kademenin sonuna kadar devam etmektedir (MEB, 2013). Ortaöğretim ikinci kademeden itibaren ise fen eğitimi fizik, kimya biyoloji gibi alanlara ayrılmaktadır (MEB, 2013). Böylece, Türkiye'de üniversite öğrenimini fen alanında yapmaya karar veren bir öğrenci ilköğretim 3.sınıftan itibaren üniversite son sınıfa kadar yaklaşık olarak 13 yıl fen eğitimi almaktadır.

Yukarıdaki paragrafta da görüldüğü gibi eğitim hayatımızın önemli bir alanını teşkil etmektedir. İlgili literatür incelendiğinde, gerek ulusal düzeyde gerekse uluslararası düzeyde eğitim sitemindeki problemlere yönelik çok sınırlı da olsa çeşitli çalışmaların yapıldığı görülmektedir. Ahmad, Rauf, Imdadullah ve Zeb (2012), Memon (2007), Rashid ve Mukhtar (2012) yaptıkları çalışmada, Pakistan eğitim sistemindeki problemleri incelemişlerdir. Eğitim sisteminin başarısız olmasında, eğitim politikalarının devamlılık arz etmemesi ve sürekli değişmesi, yolsuzluk, yeterli finansal desteğin sağlanmaması, insan kaynağı eğitiminin yetersiz olması, vizyon sahibi liderlerin eksikliği, siyasi istikrarsızlık, alt yapı yetersizlikleri, yerel ihtiyaçların ve gerçekliklerin karşılanamaması ve eğitimde merkezi yönetimin olması vb. çeşitli nedenlerden kaynaklandığı tespit edilmiştir. Boyer ve Hamil (2008) yaptıkları çalışmada ise, öğretmenlerin mesleki deformasyonu, okul aile işbirliği ya da ailelerin eğitim faaliyetlerinde yeterince yer almamaları ve öğrencilerin okuma yeteneklerindeki yetersizlikler gibi faktörlerin ABD eğitim siteminin ilerlemesinde engel teşkil ettiğini saptamışlardır. Adeyinka (1975), Odia ve Omofonmwan (2007), Udey, Ebuara, Ekpah ve Edet (2009) yaptıkları çalışmada, Nijerya eğitim sistemindeki sorunları araştırmışlardır. Yapılan bu çalışmalarda, yönetimsel ve denetimsel sorunlar, merkezi yönetimin yerel ve yöresel ihtiyaçları karşılayamama, çoklu eğitim sisteminin var olması, sürekli değişen eğitim sistemi ve öğretim programları, personel eğitimindeki yetersizlikler, ailelerin eğitimsizliği, rehberlik sorunları ve yoksulluk, eğitime yeterli finansal desteğin sağlanmaması, alt yapı sorunları, fiziki 
yetersizlikler ve öğretim materyalleri eksikliği vb. çeşitli sorunları tespit etmişlerdir. Ayrıca Sutherland (1982) yapmış olduğu çalışmada da, Kuzey İrlanda eğitim sisteminin 1952-1982 yılları arasındaki gelişimi ve problemlerini literatüre dayalı olarak incelemiştir. Ülkemizde de eğitim sisteminin sorunları ve çözümüne yönelik az da olsa çeşitli çalışmaların yapıldığı görülmektedir. Gedikoğlu (2005) yaptığı çalışmada Türk eğitim siteminde, okul öncesi orta ve yükseköğretimde okullaşma oranını düşük olduğu, eğitime yeterli bütçenin sağlanmadığı ve hemen hemen eğitimin her kademesinde bir takım sorunların olduğunu belirtmiştir. Ayrıca, Türk eğitim sisteminin, sistemsel, altyapı sorunları ve eğitim-öğretim sürecinden kaynaklanan sorunlar (Durmuşşelebi ve Bilgili, 2014) ve merkezi sınavlar, fiziki yetersizlikler, kalabalık sınıflar, ezberci eğitim, öğretmen niteliğinin yetersizliği, siyaset, finansal destek yetersizliği, öğretmen atamalarından kaynaklanan sorunlar, özel kurslar ya da dershanelerden kaynaklanan çeşitli sorunlardan dolayı başarılı bir şekilde uygulanamadığı tespit edilmiştir (Yılmaz ve Altınkurt, 2011). Demirtaş, Üstüner ve Özer (2007) yaptıkları çalışmada da, okul yönetiminde karşılaşılan sorunlar inceleme konusu olmuş: öğretmenlerden kaynaklanan, okul ikliminden kaynaklanan, öğrencilerden kaynaklanan, yönetimden kaynaklanan, okul binasından kaynaklanan vb. çeşitli sorunları tespit etmişlerdir. Cerit, Akgün, Yıldız ve Soysal (2014) çaptıkları çalışmada ise 2012-2013 eğitim öğretim yılında uygulamaya konulan yeni Türk Eğitim sisteminin sorunlarını incelemiş ve çocukların okula çok erken yaşta başlaması, fiziki yetersizlikler, eğitim-öğretim sürecinden kaynaklanan, sistem ve yapıdan kaynaklanan ve okul yönetimi personelinden kaynaklanan çeşitli sorunları tespit etmişlerdir. Özyılmaz (2013) yaptığı çalışmada da Türk Eğitim Sistemi'ndeki sorunları; eğitime ideolojik yaklaşım, eğitim uzmanlarından yeterince yararlanmama, eğitimde yönetim sorunları, eğitimde program geliştirme sorunları, öğrenci kişilik hizmetleri sorunu, çağdaş anlamda teftiş ve denetleme sorunu, eğitimde kamu ve özel okulların yeri sorunu, eğitimin finansmanı sorunu, öğretmen yetiştirme ve istihdamı sorunu, orta ve yükseköğretime geçiş sorunu, eğitim kademelerinin sorunları, öğrenme-öğretme süreci sorunu ve eğitimin millileştirilmesi sorunu vb. çeşitli sorunları tespit etmiş ve bu sorunlara çeşitli çözüm önerileri geliştirmiştir.

Daha öncede belirtildiği gibi ülkemizde genelde eğitim ve özelde ise fen eğitiminin uzun bir zaman dilimine yayıldığı görülmektedir. Ancak Keser (2005)'in de belirttiği gibi, modern çağın anlayışı göz önünde bulundurularak düzenlenen eğitim sistemleri, fen eğitimi ve öğretim programları; öğretmenlerin yeterli düzeyde hazırık yapmamaları ya da öğretmen yetersizlikleri, etkili olmayan öğrenme-öğretme teknikleri/metotları ve ölçme-değerlendirme yöntemlerinin kullanılması, kalabalık sınıfların olması ve öğretim materyalleri eksikliği vb. çeşitli nedenlerle, uygulamada istenen başarının sağlanamamasına yol açmaktadır. Gerek ulusal ve gerekse uluslararası araştırmalarda, Türkiye'deki fen eğitimi diğer ülkelerle kıyaslandığında büyük yetersizliklerin olduğu da göze çarpmaktadır (Özden, 2007). Ayrıca daha öncede belirtildiği gibi Türk Eğitim sistemi ve fen eğitimine yönelik problemlerin tespit edilmesi ve bu problemlere çözüm üretecek çalışmaların yetersiz olduğu ve yaygın olmadığı görülmektedir. Ülkemizde bir birey üniversite son sınıfa kadar fen alanında bir meslek sahibi olabilmek ve özelde de fen alanında bir öğretmen olabilmesi için uzun süre çaba sarf etmesi gerekmektedir. Bilindiği üzere öğretmen adayları özelde de fen bilgisi öğretmen adayları hem öğrenci rollünü hem de hem de gelecekteki öğretmen rolünü birlikte üstlenmiş olan bireylerdir. Bu da, farklı iki rolden, iki farklı bakış açısından yararlanarak hem eğitim sisteminin sorunlarına hem de çözüm yollarına ilişkin daha sağlıklı ve gerçekçi değerlendirmeler yapılmasına olanak sağlayacaktır (Yeşil ve Şahan, 2015). Bu bakımdan, fen öğretmen adayları, geçen bu süre zarfında acaba eğitim sistemi hakkında ne düşünmektedirler? Ne tür sorunlarla karşılaşmaktadırlar? Daha iyi bir fen eğitiminin ve eğitim sisteminin uygulanabilmesi için neler yapılması gerekir? Bu sorulara cevap aramak amacıyla bu çalışmanın bu alana önemli katkısının olacağı düşünülmektedir. Bu bakımdan bu araştırmada, fen bilgisi öğretmen adaylarının görüşlerine göre Türk eğitim sisteminin güncel problemlerinin tespit edilmesi ve bu problemlere yönelik muhtemel çözüm önerilerinin geliştirilmesi amaçlanmıştır. Böylece eğitim sisteminin aksayan yönlerinin tespit edilerek bunun fen eğitimine yansımaları incelenenmiş ve mevcut aksaklıkların giderilmesi için çeşitli çözüm önerileri geliştirilmiştir. Araştırmanın amacı doğrultusunda aşağıdaki araştırma sorularına cevap aranmaya çalışıımışır: 
3- Fen bilgisi öğretmen adaylarının görüşlerine göre, Türk Eğitim Sistemi’nin güncel problemleri nelerdir?

4- Fen bilgisi öğretmen adaylarının görüşlerine göre, Türk Eğitim Sistemi’nin mevcut problemlerine ne tür çözüm önerileri geliştirilebilir?

\section{Yöntem}

Bu araştırma, nitel araştırma yaklaşımlarından biri olan betimsel yöntem ile yürütülmüştür. Betimsel yöntemler, nicel bir yaklaşımla yapılabileceği gibi nitel bir yaklaşımla da yürütülebilir. Nitel araştırmalar, gözlem, görüşmeler ve doküman analizi gibi nitel veri toplama yöntemlerinin kullanıldığı, algıların ve olayların doğal ortamda gerçekçi ve bütüncül bir biçimde ortaya konmasına yönelik bir sürecin izlendiği bir araştırma türüdür (Yıdırım ve Şimşek, 2008). Bu çalışmada, fen bilgisi öğretmen adaylarının görüşlerinin gerçek ve doğal ortamda belirlenmesi ve verilerin toplanmasından dolayı nitel anlayışla gerçekleştirilmiştir. Bu yaklaşım doğrultusunda, fen bilgisi öğretmenliği bölümü son sınıf öğrencilerinin görüşlerine göre Türk eğitim sisteminin güncel problemleri ve muhtemel çözüm önerilerinin belirlenmesi sebebiyle mevcut durum betimlenmeye çalışılmıştır.

\section{Katılımcılar}

Araştırma, 2013-2014 öğretim yılında 518 son sınıf fen bilgisi öğretmenliği bölümü öğrencisi ile yürütülmüştür. Araştırmada, uygun örnekleme yöntemi esas alınarak örneklem seçilmiştir. Uygun örnekleme yönteminde esas alınan nokta, örneklem seçiminin kolay ulaşılabilen, yapılacak çalışmaya uygun ve elverişli olmasından kaynaklanmaktadır (McMillan ve Schumacher, 2010). Ayrıca uygun örnekleme yöntemi, zaman, para ve iş gücü kaybı az olan bir örnekleme yöntemidir (Büyüköztürk, KılıçÇakmak, Akgün, Karadeniz ve Demirel, 2008). Bu çalışmada, beş farklı bölgede bulunan dokuz farklı üniversitedeki tanıdık akademisyenler ile irtibata geçilerek 518 gönüllü fen bilgisi son sınıf öğrenciler ile yürütülmüştür.

Tablo 1. Çalışma grubunun demografik özellikleri

\begin{tabular}{lcccccc} 
Cinsiyet & $\begin{array}{c}\text { Doğu } \\
\text { Anadolu } \\
\text { Bölgesi }\end{array}$ & $\begin{array}{c}\text { Karadeniz } \\
\text { Bölgesi }\end{array}$ & $\begin{array}{c}\text { Ege } \\
\text { Bölgesi }\end{array}$ & $\begin{array}{c}\text { Güneydoğu } \\
\text { Akdeniz } \\
\text { Bölgesi }\end{array}$ & $\begin{array}{c}\text { Günadolu Bölgesi } \\
\text { Anglam }\end{array}$ & Toplam \\
\hline Kız & 162 & 71 & 43 & 36 & 24 & 336 \\
Erkek & 113 & 33 & 15 & 14 & 7 & 182 \\
Toplam (n) & & & & & & $\mathbf{5 1 8}$ \\
\hline
\end{tabular}

\section{Veri Toplama Süreci ve Analizi}

Bu çalışmada, veri toplama aracı olarak araştırmacı tarafından oluşturulan ve fen bilgisi öğretmen adaylarının yazılı görüşlerinin alınmasını sağlayan "Yapılandırılmamış Görüş Belirleme Form"u kullanılmıştır. Görüş belirleme formu iki sorundan oluşmuş: birinci soruda fen bilgisi öğretmen adaylarının görüşlerine göre Türk eğitim sisteminin güncel problemlerinin neler olduğu; ikinci soru da ise belirlenen güncel problemlere yönelik ne tür çözüm önerilerinin geliştirilebileceği araştırma konusu olmuştur.

Fen bilgisi öğretmen adaylarının yazılı görüşlerinden elde verilerin, nitel veri analizi çeşitlerinden bir olan içerik analizi yapılmıştır. Nitel veri analizi, verilerin düzenlenmesi, özetlenmesi ve verilerin yorumlanması olmak üzere üç temel aşamadan meydana gelmektedir (Büyüköztürk vd., 2008). İçerik analizinde, başlangıçta belirlenen kategoriler ve kodlar araştırmayı yönlendirmekte ve nüanslar stiller, imgeler ve anlamlar vb. diğerleri ise analiz ya da çalışma esnasında belirlendiği gibi bazen de önce kodlar oluşturulup bu kodlardan kategorilere gidilebilir (Yıldırım ve Şimşek, 2008). Bu çalışmada da, elde edilen veriler detaylı bir şekilde okunmuştur. Başlangıçta, farklı iki üniversiteden toplanan veriler, yaklaşık olarak toplam verilerin \%10, incelenmiş eğitim sitemindeki mevcut problemler ve çözüm önerileri 
oluşturulmuştur. Araştırmacılar, daha sonra analiz ettiği verileri (\% 10'luk nitel veri) tekrar inceleyerek ilk yapmış olduğu analiz ile karşılaştırmış ve az da olsa meydana gelen farklılıkları gidermiştir. Böylece araştırmacılar tarafından, eğitim sisteminin problemleri ve çözüm önerilerine yönelik fen bilgisi öğretmen adalarının görüşlerine göre kodlar oluşturulmuştur. Daha sonra mevcut kodlar incelenerek benzer olanlar aynı kategori altında birleştirilmiş ve sonuçta dört farklı kategori oluşturulmuştur. Kalan verilerin analizi bu kod ve kategoriler esas alınarak detaylı bir şekilde incelenmiştir. İçerik analizi esnasında farklı kodlar meydana geldiğinde ise ek kodlar oluşturularak uygun olan kategorinin atına yerleştirilmiştir. Her bir kodun ve kategorinin yüzdesi ve frekansı hesaplanarak tablolar halinde sunumu yapılmıştır.

\section{Sonuçlar}

Araştırmaya katılan 518 fen bilgisi öğretmen adaylarının, eğitim sisteme yönelik toplamda 2399 problem belirtmiş oldukları ve bu problemlere yönelik de toplamda 2090 çözüm önerisi geliştirmeye çalıştıkları tespit edilmiştir. Her öğretmen adayı birden fazla probleme değinmiş ve belirtmiş oldukları probleme de birden fazla çözüm önerisi getirmeye çalışmıştır. Bu çalışmadan elde edilen verilere göre, Türk Eğitim sistemindeki problemler ve çözüm önerileri; yapısal-yönetimsel problemler ( $f=772, \% 32.18)$ ve çözüm önerileri ( $f=680, \% 32.54)$; öğrenme-öğretme sürecindeki problemler $(f=844, \% 35.18)$ ve çözüm önerileri ( $f=718, \% 34.35)$, öğretmen eğitimi ile ilgili problemler ( $f=572, \% 23.84)$ ve çözüm önerileri ( $f=563, \% 26.94)$ ve son olarak ölçme-değerlendirme ile ilgili problemler ( $f=211, \%$ 8.8) ve çözüm önerileri ( $f=129, \%$ 6.17) olmak üzere dört ana kategoriye ayrılmıştır. Her kategorinin alt kodları oluşturularak mevcut problemler belirlenmiş ve bu problemlere yönelik çözüm önerileri geliştirilmiştir.

\section{Yapısal-Yönetimsel Problemler ve Çözüm Önerileri}

Bu bölümde, fen bilgisi öğretmen adaylarının görüşlerine göre, eğitim sisteminin yapısal-yönetimsel problemleri tespit edilmiş (Tablo 2) ve bu problemlere yönelik çeşitli çözüm önerileri (Tablo 3) sunulmuştur.

Tablo 2'den de anlaşılacağı gibi, eğitim sisteminin yapısal-yönetimsel problemlerine yönelik olarak otuz bir kod oluşturulmuştur. Her bir kodun kaç öğretmen tarafından ifade edildiğine dönük frekans (f) ve yüzdesi (\%) hesaplanarak Tablo 2'de sunulmuştur. Toplamda öğretmen adaylarının 2399 kere ifade ettikleri problemlerden 772 tanesi yapısal-yönetimsel problemler kategorisi altında toplanmış ve tespit edilen problemlerin \% 32.18' ini $(100 \times 772=77200,77200 / 2399=32.18)$ teşkil etmiştir. Ayrıca bu kategori altında yer alan her bir kodun yüzdesi ise 772 frekans üzerinden, örnek olarak birinci kodun yüzdesi $188 \times 100=18800$ ve $18800 / 772=23.35$ şeklinde, hesaplanmıştır. Fen bilgisi öğretmen adayları yapısalyönetimsel problemler içerisinde en çok ifade ettikleri "eğitim sisteminin sürekli olarak değişmesi" kod \% 23.35 ( $\mathrm{f}=188$ ) ile ilk sırada yer almaktadır. Daha sonra sırasıyla, "eğitimde fırsat ve imkân eşitliğinin olmaması ( $f=75, \%$ 9.71)", "eğitimden sorumlu olan yönetim mekanizmasının sürekli olarak değişmesi ve siyasete alet edilmesi ( $f=71, \%$ 9.19)", "eğitime yeterli bütçenin ayrılmaması ve önem verilmemesi ( $f=48$, $\%$ 6,21)" ve "liyakatin ve denetleme mekanizmasının yeterli düzeyde işlememesi ( $f=43, \%$ 5.56)" kodları yapısal- yönetimsel problemler içerisinde ilk sıralarda yer aldığı tespit edilmiştir.

Tablo 2. Yapısal-yönetimsel problemler

\begin{tabular}{|c|c|c|c|}
\hline & Problemler $(\mathrm{f}=772, \% 32.18)$ & f & $\%$ \\
\hline Kodlar & $n=518, \sum f=2399$ & & \\
\hline P1 & Eğitim sisteminin sürekli olarak değiştirilmesi & 188 & 23.35 \\
\hline P2 & Eğitimde fırsat ve imkân eşitsizliğinin olması & 75 & 9.71 \\
\hline P3 & $\begin{array}{l}\text { Eğitimden sorumlu olan yönetim mekanizmasının sürekli olarak değişmesi } \\
\text { ve siyasete alet edilmesi }\end{array}$ & 71 & 9.19 \\
\hline P4 & Eğitime yeterli bütçenin ayrılmaması ve önem verilmemesi & 48 & 6.21 \\
\hline P5 & Liyakatin ve denetleme mekanizmasının yeterli düzeyde işleyememesi & 43 & 5.56 \\
\hline P6 & $\begin{array}{l}\text { Eğitim sistemin de yapılan değişikliklerinde yöneticilerin, öğretmenlerin, } \\
\text { öğrencilerin, velilerin sürece dâhil edilmemesi ve yapılan değişikliklerden } \\
\text { sonradan haberlerinin olması }\end{array}$ & 38 & 4.92 \\
\hline
\end{tabular}


M. Diyaddin YAŞAR, Mustafa SÖZBiLiR- Çukurova Üniversitesi Eğitim Fakültesi Dergisi, 46(1), 2017, 165-201

\begin{tabular}{|c|c|c|c|}
\hline P7 & Eğitimde, ailelerin rolünün yeterli düzeyde sağlanamaması & 31 & 4.01 \\
\hline P8 & $\begin{array}{l}\text { Demokratik, bilimsel, özgürlükçü, çağdaş ve laik bir eğitim sisteminin } \\
\text { uygulanamaması }\end{array}$ & 30 & 3.90 \\
\hline P9 & $\begin{array}{l}\text { Üniversite mezunlarının iş bulamaması ve iş olanaklarının fazla olduğu } \\
\text { alanlara yönelmeleri }\end{array}$ & 25 & 3.23 \\
\hline P10 & Üniversite sayılarının artırılması ve üniversite niteliklerinin düşük olması & 22 & 2.84 \\
\hline P11 & $\begin{array}{l}\text { Eğitim sisteminde yapılan değişikliklerin yaşama ya da uygulamaya } \\
\text { geçirilememesi ve teoride kalması }\end{array}$ & 21 & 2.72 \\
\hline P12 & $\begin{array}{l}\text { Kültürel yapımızdan yoksun ve yabancı ülkelerin eğitim sistemlerinin direkt } \\
\text { olarak ülkemize uyarlanması }\end{array}$ & 21 & 2.72 \\
\hline P13 & $\begin{array}{l}\text { Çok kültürlü bir eğitim sisteminin olmaması ve tek tip birey yetiştiren bir } \\
\text { eğitim sisteminin olması (farklı dillere anadilde eğitim olmaması...) }\end{array}$ & 18 & 2.33 \\
\hline P14 & MEB ders kitaplarının istenilen düzeyde ve anlaşılır olmaması & 16 & 2.1 \\
\hline P15 & $\begin{array}{l}\text { Özel eğitime yeterli önemin verilmemesi ve kaynaştırmalı eğitimin etkili bir } \\
\text { şekilde yürütülememesi }\end{array}$ & 15 & 1.94 \\
\hline P16 & Eğitimin bir ticaret ve rant aracı olarak görülmesi & 15 & 1.94 \\
\hline P17 & Çocukların erken yaşta okula gönderilmesi (66 aylıkken gönderme) & 14 & 1.81 \\
\hline P18 & Eğitimin kısmen de olsa paralı olması & 12 & 1.6 \\
\hline P19 & Öğretim programlarının içerik olarak yoğun olması & 11 & 1.43 \\
\hline P20 & $\begin{array}{l}\text { Yöneticiler, öğretmen ve öğrenciler arasında koordinasyon ve iletişim } \\
\text { kopukluğunun olması. }\end{array}$ & 11 & 1.43 \\
\hline Kodlar & Problemler & f & $\%$ \\
\hline $\mathrm{P} 21$ & $\begin{array}{l}\text { Mevcut eğitim sisteminin öğrencileri sosyal yaşamdan (Öz güveni düşük, } \\
\text { kendini ifade edemeyen bireyler vs.) koparması }\end{array}$ & 10 & 1.30 \\
\hline $\mathrm{P} 22$ & Dayatmacı, baskıcı ve zoraki bir eğitimin olması & 7 & .90 \\
\hline P23 & Temel eğitimin yetersiz olması (okuma yazma bilmeyen öğrencilerin olması) & 6 & .80 \\
\hline P24 & $\begin{array}{l}\text { Fen öğretim programlarının yeterli düzeyde esnek ve öğrenci düzeyine } \\
\text { uygun olmaması }\end{array}$ & 6 & .80 \\
\hline $\mathrm{P} 25$ & Fen eğitiminde haftalık ders saatlerinin yeterli düzeyde olmaması & 5 & .65 \\
\hline P26 & $\begin{array}{l}\text { Öğrencilere yeteri kadar değer verilmemesi ve öğrencilerin bir denek olarak } \\
\text { kullanılması }\end{array}$ & 5 & .65 \\
\hline $\mathrm{P} 27$ & Eğitim yönetiminde merkeziyetçi bir anlayışın hâkim olması. & 4 & .51 \\
\hline P28 & Yeterli düzeyde yurtlar ve barınma imkânlarının olmaması & 3 & .40 \\
\hline P29 & $\begin{array}{l}\text { Öğrencelere yeterli düzeyde bursların sağlanamaması ve bazılarının } \\
\text { karşılıklı olması }\end{array}$ & 3 & .40 \\
\hline P30 & $\begin{array}{l}\text { Eğitimde, sadece öğrenme faaliyetlerine odaklanılması ve eğitim boyutunun } \\
\text { ihmal edilmesi }\end{array}$ & 3 & .40 \\
\hline P31 & Eğitim sisteminin, tüketici bireylerin yetişmesine sebep olması. & 2 & .25 \\
\hline Toplam & & 772 & 100 \\
\hline
\end{tabular}

P: Problem.

Fen bilgisi öğretmen adaylarının, eğitim sisteminin daha iyi olabilmesi için yapısal- yönetimsel problemlere yönelik geliştirdikleri çözüm önerileri Tablo 3'de yer almaktadır. Tablo 3'den de anlaşılacağı gibi, eğitim sisteminin yapısal-yönetimsel problemlerine yönelik çözüm önerileri olarak otuz yedi kod oluşturulmuştur. Her bir kodun kaç öğretmen tarafından ifade edildiğine dönük frekans (f) ve yüzdesi (\%) hesaplanarak Tablo 3'de sunulmuştur. Toplamda öğretmen adaylarının 2090 kere ifade ettikleri çözüm önerilerinden 680 tanesi yapısal-yönetimsel problemlere yönelik çözüm önerisi kategorisi altında toplanmış ve tespit edilen çözümlerin \% 32.54' ünü $(100 \times 680=68000,68000 / 2090=32.54)$ teşkil etmiştir. Ayrıca bu kategoride yer alan her bir kodun yüzdesi 680 frekans üzerinden, örnek olarak birinci kodun yüzdesi 134×100=13400 ve 13400/680= 19.70 şeklinde, hesaplanmıştır. Fen bilgisi öğretmen adaylarının yapısal-yönetimsel problemlere yönelik çözüm önerileri sırasıyla "Belli bir alt yapı ve ön hazırlık yapılarak 
ihtiyaç doğrultusunda eğitim sisteminin düzenlenmesi ve sürekli değişmemesi gerekir. (f=134, \%=19.70)", "Eğitimde, farklı bölgelerde, illerde, ilçelerde, köylerde ve okullarda fırsat ve imkân eşitliğinin sağlanması gerekir. ( $f=61, \%$ 8.97)", "Eğitimin siyasete alet edilmemesi gerekir (Devlet politikası haline gelmesi gerekir.) ( $f=45, \%$ 6.62)", "Eğitimde, liyakatin ve denetleme mekanizmasının etkili bir şekilde işlemesi gerekir. ( $f=43, \%$ 6.32)" ve "Eğitime ayrılan bütçenin arttırılması ve fen eğitimine önemin verilmesi gerekir. ( $f=41, \% 6.03)$ " kodları ilk beş sırada yer aldığı görülmektedir.

Tablo 3. Yapısal-yönetimsel problemlere yönelik çözüm önerileri

\begin{tabular}{|c|c|c|c|}
\hline Kodlar & $\begin{array}{c}\text { Çözüm önerileri ( } f=680, \% 32.54) \\
n=518, \Sigma f=2090\end{array}$ & $f$ & $\%$ \\
\hline Ç1 & $\begin{array}{l}\text { Belli bir alt yapı ve ön hazırlık yapılarak ihtiyaç doğrultusunda eğitim } \\
\text { sisteminin düzenlenmesi ve sürekli değişmemesi gerekir. }\end{array}$ & 134 & 19.70 \\
\hline Ç2 & $\begin{array}{l}\text { Eğitimde, farklı bölgelerde, illerde, ilçelerde, köylerde ve okullarda fırsat ve } \\
\text { imkân eşitliğinin sağlanması gerekir. }\end{array}$ & 61 & 8.97 \\
\hline Ç3 & $\begin{array}{l}\text { Eğitimin siyasete alet edilmemesi gerekir (Devlet politikası haline gelmesi } \\
\text { gerekir.). }\end{array}$ & 45 & 6.62 \\
\hline Ç4 & $\begin{array}{l}\text { Eğitimde, liyakatin ve denetleme mekanizmasının etkili bir şekilde işlemesi } \\
\text { gerekir. }\end{array}$ & 43 & 6.32 \\
\hline Ç5 & $\begin{array}{l}\text { Eğitime ayrılan bütçenin arttırılması ve fen eğitimine önemin verilmesi } \\
\text { gerekir. }\end{array}$ & 41 & 6.03 \\
\hline Ç6 & Eğitim yöneticilerinin, eğitimci olması ve gelişi güzel seçilmemesi gerekir & 36 & 5.29 \\
\hline Kodlar & Çözüm önerileri & f & $\%$ \\
\hline Ç7 & $\begin{array}{l}\text { İstihdam politikasının incelenmesi ve ihtiyaca göre öğrencilerin üniversiteye } \\
\text { alınması gerekir. }\end{array}$ & 31 & 4.56 \\
\hline Ç8 & $\begin{array}{l}\text { Toplumun ihtiyaçlarına, kültürel yapısına ve öğrenci özelliklerine uygun bir } \\
\text { eğitim sisteminin oluşturulması gerekir }\end{array}$ & 30 & 4.41 \\
\hline Ç9 & $\begin{array}{l}\text { Bilimsel, demokratik, evrensel, laik ve özgürlükçü bir eğitim sisteminin } \\
\text { yapılandırılması gerekir. }\end{array}$ & 29 & 4.26 \\
\hline Ç10 & $\begin{array}{l}\text { Eğitim sistemi yapılandırıldığında, eğitim yöneticileri, öğretmenler, } \\
\text { öğrenciler, aileler ve geniş kitlelerden fikirler alınması gerekir. }\end{array}$ & 27 & 3.97 \\
\hline Ç11 & $\begin{array}{l}\text { Eğitimde ailelerin rolü arttırımalı ve aileler bilinçlendirilmesi gerekir (okul } \\
\text { aile işbirliği işlevsel hale gelmelidir). }\end{array}$ & 27 & 3.97 \\
\hline Ç12 & $\begin{array}{l}\text { Yenilenen eğitim sistemi hakkında toplumun, yöneticilerin, öğretmenlerin, } \\
\text { velilerin ve öğrencilerin bilgilendirilmesi gerekir. }\end{array}$ & 19 & 2.70 \\
\hline Ç13 & $\begin{array}{l}\text { Eğitimde, sosyal, özgüvene sahip, girişimci ve sorumluluk sahibi bireylerin } \\
\text { yetiştirilmesi gerekir. }\end{array}$ & 18 & 2.65 \\
\hline Ç14 & $\begin{array}{l}\text { Gelişmiş ülkelerin eğitim sistemlerini yapılandırırken ve sorunlarına çözüm } \\
\text { ararken nasıl bir yol izlediklerinin incelenmesi gerekir. }\end{array}$ & 16 & 2.35 \\
\hline Ç15 & $\begin{array}{l}\text { Çok kültürlü eğitimin sağlanması gerekir (Tek tip birey yetiştirilmemesi, farklı } \\
\text { dillerde anadilde eğitimin sağlanması gerekir.) }\end{array}$ & 16 & 2.35 \\
\hline Ç16 & $\begin{array}{l}\text { MEB ders kitapları anlaşılır bir dille yazııması ve öğrenci düzeylerine göre } \\
\text { hazırlanması gerekir. }\end{array}$ & 14 & 2.06 \\
\hline Ç17 & Özel eğitime önem verilmeli ve yaygınlaştırılması gerekir. & 12 & 1.76 \\
\hline Ç18 & $\begin{array}{l}\text { Öğretim programlarının içerik konu ve bilgi bakımından sadeleştirilmesi, } \\
\text { esnek ve öğrenci düzeyine uygun olarak geliştirilmesi gerekir. }\end{array}$ & 10 & 1.47 \\
\hline Ç19 & $\begin{array}{l}\text { Öğrencilere verilen bursların karşılıksız olması, yaygınlaştırılması ve } \\
\text { miktarının artııılması gerekir. }\end{array}$ & 9 & 1.32 \\
\hline Ç20 & Eğitim ve öğretim faaliyetlerinin birlikte yürütülmesi gerekir. & 9 & 1.32 \\
\hline Ç21 & $\begin{array}{l}\text { Eğitimin, tüm kademelerde parasız olması gerekir (özel ilköğretim, } \\
\text { ortaöğretim, üniversite vb. olmamalıdır). }\end{array}$ & 7 & 1.03 \\
\hline Ç22 & $\begin{array}{l}\text { Yöneticilerin eğitim ile ilgili kararlar alırken vicdani, mantıklı, bilimsel } \\
\text { davranması ve çözüm üretici olması gerekir. }\end{array}$ & 6 & .88 \\
\hline
\end{tabular}


M. Diyaddin YAŞAR, Mustafa SÖzBiLiR- Çukurova Üniversitesi Eğitim Fakültesi Dergisi, 46(1), 2017, 165-201

\begin{tabular}{llcc}
\hline Ç23 & $\begin{array}{l}\text { Çocukların çok küçük yaşta okula gönderilmemesi ya da oyunlarla fen } \\
\text { eğitiminin sağlanması gerekir. }\end{array}$ & 5 & .74 \\
Ç24 & Eğitimin bir ticaret ve rant aracı olmaktan çıkarılması gerekir. & 5 & .74 \\
Ç25 & Eğitimde, kılık kıyafet serbest olması gerekir. & 5 & .74 \\
Ç26 & Temel eğitime önem verilmesi gerekir (etkili dil eğitimi olmalıdır). & 4 & .59 \\
Ç27 & Yurt ve barınma yerlerinin iyileştirilmesi ve sayılarının arttırılması gerekir. & 3 & .44 \\
Ç28 & Akademisyenler ile yöneticiler, öğretmenler ve öğrenciler arasındaki bağın & 3 & .44 \\
& kurulması ve güçlendirilmesi gerekir. & 3 & .44 \\
Ç29 & Fen eğitiminde, haftalık ders saatlerinin arttırılması gerekir. & .29 \\
Ç30 & Fen fakültesinde öğrenci sayısı azaltılmalı ve asıl işlevinin yerine getirilmesi & 2 & \\
& sağlanmaya çalışımalıdır. & 2 & .29 \\
Ç31 & Eğitimde özelleşmeye gidilmelidir. & 2 & .29 \\
Ç32 & Eğitiminde, meslek okullarının sayısı arttırılmalı ve mesleki eğitime önem & & \\
& verilmelidir. & 1 & .15 \\
Ç33 & Okul öncesi eğitimin zorunlu olması gerekir. & 1 & .15 \\
Ç34 & Okul açılış kapanış tarihleri, bölgesel özelliklere göre düzenlenmesi gerekir. & 1 \\
Ç35 & Ders kitaplarının yanında performans kitaplarını hazırlanması gerekir & 1 & .15 \\
Ç36 & Eğitimde, üniversitede zorunlu derslerin olmaması gerekir & 1 & .15 \\
Ç37 & Tüm gün eğitim öğretimin olması ve sabahçı-öğleci ayrımın olmaması gerekir. & 1 & .15 \\
Toplam & & $\mathbf{6 8 0}$ & $\mathbf{1 0 0}$ \\
\hline
\end{tabular}

Ç: Çözüm.

\section{Öğrenme-Öğretme Sürecindeki Problemler ve Çözüm Önerileri}

Bu bölümde, fen bilgisi öğretmen adaylarının görüşlerine göre, eğitim sisteminin öğrenme-öğretme süreci problemleri tespit edilmiş (Tablo 4) ve bu problemlere yönelik çeşitli çözüm önerileri (Tablo 5) sunulmuştur.

Tablo 4'den de anlaşılacağı gibi, öğrenme-öğretme süreci problemlerine yönelik olarak on beş kod oluşturulmuştur. Her bir kodun kaç öğretmen tarafından ifade edildiğine dönük frekans (f) ve yüzdesi (\%) hesaplanarak Tablo 4'de sunulmuştur. Toplamda öğretmen adaylarının 2399 kere ifade ettikleri problemlerden 844 tanesi öğrenme-öğretme süreciyle ilgili problemler kategorisi altında toplanmış ve tespit edilen problemlerin \% 35.18' ini $(100 x 844=84400,84400 / 2399=35.18)$ teşkil ederek en çok belirtilen problemler olarak tespit edilmiştir. Ayrıca bu kategoride yer alan her bir kodun yüzdesi 844 frekans üzerinden, örnek olarak birinci kodun yüzdesi 160x100=16000 ve 16000/844= 18.96 şeklinde, hesaplanmıştır. Öğretmen adayları, öğrenme-öğretme süreci problemleri içerisinde en çok ifade ettikleri "Fen eğitiminde, teorik ve ezbere dayalı öğretim faaliyetlerinin gerçekleşmesi (Geleneksel anlayışın hâkim olması...) ve öğrenmede kalıcılığın sağlanamaması" kod \%18.96 ( $\mathrm{f}=160$ ) ile ilk sırada olduğu görülmüştür. Daha sonra sırasıyla, "Fen eğitiminde, fiziki yetersizliklerin (araç, gereç materyaller, laboratuar malzemeleri, sınıfların kalabalık olması, uygun okul ve sınıf koşullarının olmaması vb.) olması ( $f=146, \%$ 17.30)", "Fen eğitiminde, öğretmen merkezli anlayışın ve anlatım yönteminin ağırlıkta olması ( $f=122, \%$ 14.50)", "Fen eğitiminin öğrenci ilgi, ihtiyaç, beklenti ve becerilerinden bağımsız bir şekilde yürütülmesi ( $f=121, \% 14.34)$ ve "Fen eğitiminde, bireysel farklılıkların dikkate alınmaması ( $f=75, \%$ 8.89)" kodları da öğrenme-öğretme süreciyle ilgili problemlerde ilk sıralarda yer aldığı tespit edilmiştir.

Tablo 4. Öğrenme-öğretme süreciyle ilgili problemler

\begin{tabular}{|c|c|c|c|}
\hline Kodlar & $\begin{array}{c}\text { Problemler }(f=844, \%=35.18) \\
n=518, \sum f=2399\end{array}$ & f & $\%$ \\
\hline P1 & $\begin{array}{l}\text { Fen eğitiminde, teorik ve ezbere dayalı öğretim faaliyetlerinin } \\
\text { gerçekleşmesi (Geleneksel anlayışın hâkim olması...) ve öğrenmede } \\
\text { kalıcılığın sağlanamaması }\end{array}$ & 160 & 18.96 \\
\hline P2 & $\begin{array}{l}\text { Fen eğitiminde, fiziki yetersizliklerin (araç, gereç materyaller, laboratuar } \\
\text { malzemelerin eksikliği, sınıfların kalabalık olması, uygun okul ve sınıf } \\
\text { koşullarının olmaması vb.) olması }\end{array}$ & 146 & 17.30 \\
\hline
\end{tabular}


M. Diyaddin YAŞAR, Mustafa SÖZBiLiR- Çukurova Üniversitesi Eğitim Fakültesi Dergisi, 46(1), 2017, 165-201

\begin{tabular}{|c|c|c|c|}
\hline P3 & $\begin{array}{l}\text { Fen eğitiminde, öğretmen merkezli anlayışın ve anlatım yönteminin ağırlıkta } \\
\text { olması }\end{array}$ & 122 & 14.50 \\
\hline P4 & $\begin{array}{l}\text { Fen eğitiminin öğrenci ilgi, ihtiyaç, beklenti ve becerilerinden bağımsız bir } \\
\text { şekilde yürütülmesi }\end{array}$ & 121 & 14.34 \\
\hline P5 & Fen eğitiminde, bireysel farklılıkların dikkate alınmaması & 75 & 8.89 \\
\hline P6 & $\begin{array}{l}\text { Fen eğitiminde uygulamaya dayalı öğrenme-öğretme (laboratuar destekli } \\
\text { öğretim, sınıf içi ve dışı etkinlikler vb.) faaliyetlerinin yeterli düzeyde } \\
\text { olmaması }\end{array}$ & 67 & 7.94 \\
\hline P7 & $\begin{array}{l}\text { Danışmanlık ve rehberlik hizmetlerinin yetersiz olması ve öğrencilerin yanlış } \\
\text { yönlendirmesi }\end{array}$ & 37 & 4.38 \\
\hline P8 & $\begin{array}{l}\text { Fen eğitiminde, bilgi ve iletişim teknolojilerinden ve görsel-işitsel araç gereç } \\
\text { ve materyallerden yeterince yararlanılmaması }\end{array}$ & 22 & 2.61 \\
\hline P9 & $\begin{array}{l}\text { Fen eğitiminde, sınıf içi tartışmalara yeterli düzeyde yer verilmemesi } \\
\text { (öğrenci görüş ve düşüncelerinin önemsenmemesi) }\end{array}$ & 18 & 2.13 \\
\hline P10 & $\begin{array}{l}\text { Fen eğitiminde, öğrencilerde üst düzey düşünme becerilerinin (araştırma, } \\
\text { sorgulama, analiz, sentez vb.) sağlanamaması }\end{array}$ & 16 & 1.90 \\
\hline P11 & $\begin{array}{l}\text { Fen eğitiminde, öğretmen ile öğrenciler arasında iletişim kopukluğunun ve } \\
\text { sorunlarının olması }\end{array}$ & 16 & 1.90 \\
\hline P12 & $\begin{array}{l}\text { Fen eğitiminin gerçek yaşam ile bağlantısının yeterli düzeyde } \\
\text { sağlanamaması }\end{array}$ & 14 & 1.66 \\
\hline Kodlar & Problemler & $\mathbf{f}$ & $\%$ \\
\hline P13 & $\begin{array}{l}\text { Fen eğitiminde öğrencilere yeterli düzeyde alan bilgisinin verilememesi ve } \\
\text { öğrencilerin özel kurslara yönelmeleri }\end{array}$ & 14 & 1.66 \\
\hline P14 & $\begin{array}{l}\text { Fen eğitiminde, öğretmenlerin öğrenciler arasında ayrım yapması (çalışkan } \\
\text { ve durumu iyi olan öğrencilere yönelmeleri...) }\end{array}$ & 10 & 1.18 \\
\hline P15 & $\begin{array}{l}\text { Fen eğitiminde, yaparak yaşayarak öğrenmenin yeterli düzeyde } \\
\text { gerçekleştirilmemesi }\end{array}$ & 6 & .71 \\
\hline Toplam & & 844 & 100 \\
\hline
\end{tabular}

P: Problem.

Fen bilgisi öğretmen adaylarının, eğitim sisteminin daha iyi olabilmesi için öğrenme-öğretme süreci problemlerine yönelik geliştirdikleri çözüm önerileri Tablo 5'te yer almaktadır. Tablo 5'ten de anlaşılacağı gibi, öğrenme-öğretme süreci problemlerine yönelik çözüm önerileri olarak on beş kod oluşturulmuştur. Her bir kodun kaç öğretmen tarafından ifade edildiğine dönük frekans (f) ve yüzdesi (\%) hesaplanarak Tablo 5'te sunulmuştur. Toplamda öğretmen adaylarının 2090 kere ifade ettikleri çözüm önerilerinden 718 tanesi öğrenme-öğretme süreci problemlerine yönelik geliştirilen çözüm önerisi kategorisi altında toplanmış ve tespit edilen çözümlerin \% 34.35' ini (100x718=71800, $71800 / 2090=34.35$ ) teşkil etmiştir. Ayrıca bu kategoride yer alan her bir kodun yüzdesi 718 frekans üzerinden, örnek olarak birinci kodun yüzdesi $131 \times 100=13100$ ve $13100 / 718=18.25$ şeklinde, hesaplanmıştır. Fen bilgisi öğretmen adaylarının öğrenme-öğretme süreci problemlerine yönelik çözüm önerileri sırasıyla "Fen eğitiminde, öğrenci ilgi, ihtiyaç, düzey, beklenti ve yetenekleri doğrultusunda öğretimin sağlanması gerekir. ( $f=131, \%=18.25)$ ", "Fen eğitiminde, farklı alternatif öğrenci merkezli yaklaşım ve yöntemler kullanılmalı ve yaygınlaştırılmalıdır. ( $f=129$, \% 17.97)", "Fen eğitiminde fiziki şartların düzeltilmesi (laboratuar ve malzemeleri, materyaller ve sınıf mevcutları vs.) gerekir. ( $f=106, \%$ 14.76)", "Fen eğitiminde, uygulamaya dönük (laboratuar destekli, sınıf içi ve dışı öğrenme etkinlikleri vs.) öğretim faaliyetlerinin yaygınlaştırılması gerekir. ( $f=84, \% 11.70)$ " ve "Fen eğitiminde, bilgi iletişim teknolojileri, görsel araç gereç ve materyaller etkili bir şekilde kullanılmalıdır. ( $f=57, \%$ 7.93)" kodları ilk beşte yer aldığı görülmektedir. 
Tablo 5. Öğrenme-öğretme süreciyle ilgili sorunlara yönelik çözüm önerileri

\begin{tabular}{|c|c|c|c|}
\hline Kodlar & $\begin{array}{c}\text { Çözüm önerileri ( } f=718, \% 34.35) \\
n=518, \Sigma f=2090\end{array}$ & $f$ & $\%$ \\
\hline Ç1 & $\begin{array}{l}\text { Fen eğitiminde, öğrenci ilgi, intiyaç, düzey, beklenti ve yetenekleri } \\
\text { doğrultusunda öğretimin sağlanması gerekir. }\end{array}$ & 131 & 18.25 \\
\hline Ç2 & $\begin{array}{l}\text { Fen eğitiminde, farklı alternatif öğrenci merkezli yaklaşım ve yöntemler } \\
\text { kullanılmalı ve yaygınlaştırımalıdır. }\end{array}$ & 129 & 17.97 \\
\hline Ç3 & $\begin{array}{l}\text { Fen eğitiminde fiziki şartların düzeltilmesi (laboratuar ve malzemeleri, } \\
\text { materyaller ve sınıf mevcutları vs.) gerekir. }\end{array}$ & 106 & 14.76 \\
\hline Ç4 & $\begin{array}{l}\text { Fen eğitiminde, uygulamaya dönük (laboratuar destekli, sınıf içi ve dışı } \\
\text { öğrenme etkinlikleri vs.) öğretim faaliyetlerinin yaygınlaştırılması gerekir. }\end{array}$ & 84 & 11.70 \\
\hline Ç5 & $\begin{array}{l}\text { Fen eğitiminde, bilgi iletişim teknolojileri, görsel araç gereç ve materyaller } \\
\text { etkili bir şekilde kullanılmalıdır. }\end{array}$ & 57 & 7.93 \\
\hline Ç6 & $\begin{array}{l}\text { Fen eğitiminde, öğrencilerin bireysel farklılıklarının dikkate alınması } \\
\text { gerekir. }\end{array}$ & 44 & 6.13 \\
\hline Ç7 & $\begin{array}{l}\text { Fen eğitiminin, gerçek yaşam ile bağlantılı olarak öğretiminin sağlanması } \\
\text { gerekir. }\end{array}$ & 28 & 3.90 \\
\hline Ç8 & $\begin{array}{l}\text { Fen eğitiminde, rehberlik, danışmanlık ve yönlendirme faaliyetlerinin etkili } \\
\text { bir şekilde yürütülmesi gerekir. }\end{array}$ & 28 & 3.90 \\
\hline Ç9 & Fen eğitiminde, yaparak ve yaşayarak öğrenmenin sağlanması gerekir. & 26 & 3.62 \\
\hline
\end{tabular}

\begin{tabular}{|c|c|c|c|}
\hline Kodlar & Çözüm önerileri & $f$ & $\%$ \\
\hline Ç10 & $\begin{array}{l}\text { Fen eğitiminde, öğrencilerin üst düzey zihinsel gelişimlerine odaklanılması } \\
\text { (araştırma, sorgulamaya dayalı, problemlere çözüm üretebilme vb.) } \\
\text { gerekir. }\end{array}$ & 26 & 3.62 \\
\hline Ç11 & $\begin{array}{l}\text { Fen eğitiminde, konu içerikleri azaltılmalı, derinlemesine anlamlı ve kalıcı } \\
\text { öğrenmenin sağlanması gerekir. }\end{array}$ & 19 & 2.65 \\
\hline Ç12 & $\begin{array}{l}\text { Fen eğitiminde, sınıf içi tartışmalara ağırlık verilmesi ve öğrenci görüşlerinin } \\
\text { önemsenmesi gerekir. }\end{array}$ & 18 & 2.51 \\
\hline Ç13 & $\begin{array}{l}\text { Fen eğitiminde, öğretmen-öğrenci ve öğrenci-öğrenci arasında etkili } \\
\text { iletişim kanallarının kullanılması gerekir. }\end{array}$ & 17 & 2.37 \\
\hline Ç14 & $\begin{array}{l}\text { Öğretmenlerin sadece okul içinde değil okul dışında da öğrencilerine } \\
\text { zaman ayırması gerekir. }\end{array}$ & 3 & .18 \\
\hline Ç15 & Fen eğitiminde, öğrenmeyi öğrenme esas alınması gerekir. & 2 & .28 \\
\hline Toplam & & 718 & 100 \\
\hline
\end{tabular}

Ç: Çözüm.

\section{Öğretmen Eğitimi ile ilgili Problemler ve Çözüm Önerileri}

Bu bölümde, fen bilgisi öğretmen adaylarının görüşlerine göre, öğretmen eğitimine dönük problemler tespit edilmiş (Tablo 6) ve bu problemlere yönelik çeşitli çözüm önerileri (Tablo 7) sunulmuştur.

Tablo 6.'dan da anlaşılacağı gibi, öğretmen eğitimiyle ilgili problemlere yönelik yirmi kod oluşturulmuştur. Her bir kodun kaç öğretmen tarafından ifade edildiğine dönük frekans (f) ve yüzdesi (\%) hesaplanarak Tablo 6'da sunulmuştur. Toplamda öğretmen adaylarının 2399 kere ifade ettikleri problemlerden 572 tanesi öğretmen eğitimiyle ilgili problemler kategorisi altında toplanmış ve tespit edilen problemlerin \% 23.84' ünü $(100 \times 572=57200,57200 / 2399=23.84)$ teşkil etmiştir. Ayrıca bu kategoride yer alan her bir kodun yüzdesi 572 frekans üzerinden, örnek olarak birinci kodun yüzdesi $97 \times 100=9700$ ve $9700 / 572=16.96$ şeklinde, hesaplanmıştır. Fen bilgisi öğretmen adaylarını öğretmen eğitimiyle ilgili problemler içerisinde en çok ifade ettikleri "Öğretmenlik niteliğine sahip olmayanların 
öğretmen olarak görev yapması ve fen derslerine girmeleri (Ücretli öğretmenlik, fen fakülteleri vb. diğer branşlar...)" kod \%16.96 (f=97) ile ilk sırada olduğu görülmüştür. Daha sonra sırasıyla, "Öğretmen eğitiminin ve eğitim fakültelerin niteliğinin düşük olması ( $f=92, \% 16.08)$ ", "Öğretmenlerin alan bilgisi ve donanım açısından yetersiz olması (yeterli bilgi verememesi, yeniliğe açık olmamaları, teknolojiyi kullanmamaları vb.) ( $f=72, \%$ 12.59)", "Fen eğitiminde, öğretmenlerin sayısının az olması ve yeterli düzeyde öğretmen atamasının yapılmaması... (f=64, \% 11.19)" ve "KPSS (Kamu Personeli Seçme Sınavı)'e göre öğretmenlerin atanması ve gerçeği yansıtmaması ( $f=55, \% 9.62)$ " kodları öğretmen eğitimiyle ilgili problemler içerisinde ilk sıralarda yer aldı̆̆ı tespit edilmiştir.

Tablo 6. Öğretmen eğitimi ile ilgili problemler

\begin{tabular}{|c|c|c|c|}
\hline & Problemler $(f=572, \%$ 23.84) & $f$ & $\%$ \\
\hline Kodlar & $n=518, \sum f=2399$ & & \\
\hline P1 & $\begin{array}{l}\text { Öğretmenlik niteliğine sahip olmayanların öğretmen olarak görev yapması } \\
\text { ve fen derslerine girmeleri (Ücretli öğretmenlik, fen fakülteleri vb. diğer } \\
\text { branşlar...) }\end{array}$ & 97 & 16.96 \\
\hline $\mathrm{P} 2$ & Öğretmen eğitiminin ve eğitim fakültelerin niteliğinin düşük olması & 92 & 16.08 \\
\hline P3 & $\begin{array}{l}\text { Öğretmenlerin alan bilgisi ve donanım açısından yetersiz olması (yeterli } \\
\text { bilgi verememesi, yeniliğe açık olmamaları, teknolojiyi kullanmamaları vb.) }\end{array}$ & 72 & 12.59 \\
\hline P4 & $\begin{array}{l}\text { Fen eğitiminde, öğretmenlerin sayısının az olması ve yeterli düzeyde } \\
\text { öğretmen atamasının yapılmaması... }\end{array}$ & 64 & 11.19 \\
\hline P5 & $\begin{array}{l}\text { KPSS (Kamu Personeli Seçme Sınavı)'e göre öğretmenlerin atanması ve } \\
\text { gerçeği yansıtmaması }\end{array}$ & 55 & 9.62 \\
\hline P6 & Yaşlı öğretmenlerin verimli olamaması & 50 & 8.74 \\
\hline Kodlar & Problemler & $f$ & $\%$ \\
\hline P7 & $\begin{array}{l}\text { Eğitim fakültesi dışındakilere formasyon eğitimimin verilmesi ve verimli } \\
\text { olmaması }\end{array}$ & 40 & 6.99 \\
\hline P8 & $\begin{array}{l}\text { Mesleki deformasyonun olması ve öğretmenlerin mesleklerine gereken } \\
\text { özeni göstermemesi }\end{array}$ & 25 & 4.37 \\
\hline P9 & Genç neslin öğretmen olarak atanamaması & 17 & 2.97 \\
\hline P10 & Eğitimcilerin maddi ve ekonomik sorunlarının olması & 14 & 2.45 \\
\hline P11 & $\begin{array}{l}\text { Öğretmen adaylarının aldıkları eğitim ile gerçek öğretmenlik mesleğini icra } \\
\text { ettiklerinde uyuşmazlıkların olması }\end{array}$ & 13 & 2.27 \\
\hline $\mathrm{P} 12$ & $\begin{array}{l}\text { Öğretmen eğitiminde, uygulamaya dayalı eğitimin yeterli düzeyde } \\
\text { olmaması ve uygulama derslerinin çoğunlukla son yıllara sığdırılmaya } \\
\text { çalışılması }\end{array}$ & 8 & 1.40 \\
\hline P13 & $\begin{array}{l}\text { Öğretmenlik mesleğinin itibarının düşürülmesi ve devletin yeterince sahip } \\
\text { çıkmaması }\end{array}$ & 7 & 1.22 \\
\hline P14 & $\begin{array}{l}\text { Öğretmen eğitimindeki seçmeli derslerin öğrenciler tarafından } \\
\text { seçilememesi }\end{array}$ & 4 & .70 \\
\hline P15 & Hizmet içi kurslarını yeterince olmaması ve niteliksiz olması & 4 & .70 \\
\hline P16 & Fen fakülteleri ile eğitim fakültelerinin aynı işleve getirilmesi & 3 & .53 \\
\hline P17 & Eğitimde öğretmenlere verilen yetkilerin sınırlı ve az olması. & 3 & .53 \\
\hline P18 & Yıl içerisinde, öğretmenlerin yerlerinin değişmesi ve atamalarının yapılması & 2 & .35 \\
\hline P19 & Öğretmenlerin başarısızlığı öğrencilere yüklemesi & 1 & .17 \\
\hline P20 & Öğretmen eğitiminde alan dışı derslerin çok olması & 1 & .17 \\
\hline Toplam & & 572 & 100 \\
\hline
\end{tabular}

P: Problem.

Fen bilgisi öğretmen adaylarının, eğitim sisteminin daha iyi olabilmesi için öğretmen eğitimi problemlerine yönelik geliştirdikleri çözüm önerileri Tablo 7'de yer almaktadır. Tablo 7'den de anlaşılacağı gibi, öğretmen eğitimi problemlerine yönelik çözüm önerileri olarak yirmi üç kod oluşturulmuştur. Her bir kodun kaç öğretmen tarafından ifade edildiğine dönük frekans (f) ve yüzdesi (\%) 
hesaplanarak Tablo 7'de sunulmuştur. Toplamda öğretmen adaylarının 2090 kere ifade ettikleri çözüm önerilerinden 563 tanesi öğretmen eğitimi problemlerine yönelik geliştirilen çözüm önerisi kategorisi altında toplanmış ve tespit edilen çözümlerin \% 26.94' ünü $(100 x 563=56300,56300 / 2090=26.94)$ teşkil etmiştir. Ayrıca bu kategoride yer alan her bir kodun yüzdesi 563 frekans üzerinden, örnek olarak birinci kodun yüzdesi $118 \times 100=11800$ ve $11800 / 563=20.96$ şeklinde, hesaplanmıştır. Fen bilgisi öğretmen adaylarının öğretmen eğitimi problemlerine yönelik çözüm önerileri sırasıyla belirtmiş oldukları "Öğretmen eğitiminin kalitesi ve eğitim fakültelerinin niteliğinin arttırılması gerekir. (Ön koşul şartlar belirlenmeli, düşük puanlı öğrenciler alınmamalı, öğrenci sayısı azaltılmalı, etkili alan bilgisi eğitimi sağlanmalı ve yeni yaklaşımlara göre eğitim düzenlenmeli vb.) ( $f=118, \%=20.96)$ ", "Yeterince fen öğretmen ataması yapılması (Ücretli öğretmenlik kaldırılmalı...) gerekir ( $f=69, \%$ 12.26).", "Yaşlı ve verimli olmayan öğretmenlerin emekliye ayrılması gerekir (emeklilik yaşı düşürülmelidir). ( $f=67, \%$ 11.90)", "Genç ve dinamik fen öğretmenlerinin ya da eğitimcilerinin önü açılmalı ve mesleğe getirilmesi gerekir. ( $f=51, \%$ 9.06)" ve "Eğitimci olanların öğretmenlik mesleğini icra etmesi gerekir (Formasyon eğitimi kaldırılmalı, fen fakülteleri asıl işlevini yerine getirmelidir. ( $f=41, \% 7.28)$ ” kodların ilk beşte yer aldığı saptanmıştır.

Tablo 7. Öğretmen eğitimiyle ilgili problemlere yönelik çözüm önerileri

\begin{tabular}{|c|c|c|c|}
\hline & Çözüm önerileri (f=563, \% 26.94) & $f$ & $\%$ \\
\hline Kodlar & $n=518, \sum f=2090$ & & \\
\hline Ç1 & $\begin{array}{l}\text { Öğretmen eğitiminin kalitesi ve eğitim fakültelerinin niteliğinin arttırılması } \\
\text { gerekir. (Ön koşul şartlar belirlenmeli, düşük puanlı öğrenciler alınmamalı, } \\
\text { öğrenci sayısı azaltılmalı, etkili alan bilgisi eğitimi sağlanmalı ve yeni } \\
\text { yaklaşımlara göre eğitim düzenlenmeli vb.). }\end{array}$ & 118 & 20.96 \\
\hline Ç2 & $\begin{array}{l}\text { Yeterince fen öğretmen ataması yapılması (Ücretli öğretmenlik kaldırılmalı...) } \\
\text { gerekir. }\end{array}$ & 69 & 12.26 \\
\hline Ç3 & $\begin{array}{l}\text { Yaşlı ve verimli olmayan öğretmenlerin emekliye ayrılması gerekir (emeklilik } \\
\text { yaşı düşürülmelidir). }\end{array}$ & 67 & 11.90 \\
\hline Ç4 & $\begin{array}{l}\text { Genç ve dinamik fen öğretmenlerinin ya da eğitimcilerinin önü açılmalı ve } \\
\text { mesleğe getirilmesi gerekir }\end{array}$ & 51 & 9.06 \\
\hline Ç5 & $\begin{array}{l}\text { Eğitimci olanların öğretmenlik mesleğini icra etmesi gerekir (Formasyon } \\
\text { eğitimi kaldırılmalı, fen fakülteleri asıl işlevini yerine getirmelidir). }\end{array}$ & 41 & 7.28 \\
\hline Ç6 & $\begin{array}{l}\text { Fen eğitiminde, öğretmenler için etkili ve verimli hizmet içi kurslarının } \\
\text { düzenlenmesi gerekir. }\end{array}$ & 38 & 6.75 \\
\hline Ç7 & $\begin{array}{l}\text { Öğretmen atamalarında, öğretmen adaylarının niteliğinin (alan bilgisi, } \\
\text { öğretmenlik yeterlilikleri vs.) de göz önünde bulundurulması gerekir. }\end{array}$ & 29 & 5.15 \\
\hline Ç8 & $\begin{array}{l}\text { Öğretmen atamalarında liyakat sağlanması ve sadece KPPS (Kamu Personeli } \\
\text { Seçme Sınavı) ile olmaması gerekir. }\end{array}$ & 29 & 5.15 \\
\hline Ç9 & $\begin{array}{l}\text { Fen eğitiminde, her öğretmen kendi branşında derse girmesi gerekir (Sınıf } \\
\text { öğretmenleri, fizik, kimya ve biyoloji öğretmenlerinin fen bilgisi derslerine } \\
\text { girmemesi vb. gerekir.). }\end{array}$ & 28 & 4.97 \\
\hline Ç10 & $\begin{array}{l}\text { Eğitime gönül verenlerin ve sevenlerin öğretmenlik mesleğini yapması } \\
\text { gerekir. }\end{array}$ & 21 & 3.73 \\
\hline Ç11 & $\begin{array}{l}\text { Eğitim derslerinin, öğretmenlik uygulamalarının ve stajlarının verimli hale } \\
\text { getirilmesi ve yaygınlaştırılması (tüm yıllara yayılmalı ve daha erken sınıflarda } \\
\text { olması gerekir) gerekir. }\end{array}$ & 15 & 2.66 \\
\hline Ç12 & $\begin{array}{l}\text { Eğitimcilerin, öğretmenlerin maddi ve manevi ihtiyaçları karşılanması ve } \\
\text { refah düzeylerinin arttırılması gerekir. }\end{array}$ & 14 & 2.49 \\
\hline Ç13 & $\begin{array}{l}\text { Öğretmenlerin, donanımlı, yeniliğe açık olması ve sürekli kendilerini } \\
\text { geliştirmesi gerekir. }\end{array}$ & 9 & 1.60 \\
\hline Ç14 & $\begin{array}{l}\text { Öğretmenlik mesleğinin sevdirilmesi ve toplumda saygın bir yere getirilmesi } \\
\text { gerekir. }\end{array}$ & 8 & 1.42 \\
\hline
\end{tabular}


M. Diyaddin YAŞAR, Mustafa SÖZBiLiR- Çukurova Üniversitesi Eğitim Fakültesi Dergisi, 46(1), 2017, 165-201

\begin{tabular}{|c|c|c|c|}
\hline Ç15 & $\begin{array}{l}\text { Öğretmen yeterliliklerinin, her yıl incelenmesi ve sınava tabi tutulması } \\
\text { gerekir. }\end{array}$ & 7 & 1.24 \\
\hline Ç16 & Eğitimde öğretmenlerin, yetki ve haklarının arttırılması gerekir. & 4 & .71 \\
\hline Ç17 & $\begin{array}{l}\text { Öğretmen adaylarının aldıkları eğitim ile gerçek meslek hayatlarındaki } \\
\text { uygulamaları arasında ilişkinin sağlanması gerekir }\end{array}$ & 4 & .71 \\
\hline Ç18 & $\begin{array}{l}\text { Öğretmen adaylarına uygulama derslerinde maaş verilmesi ve öğretmenlik } \\
\text { mesleğinin benimsetilmesi gerekir. }\end{array}$ & 3 & .53 \\
\hline Ç19 & $\begin{array}{l}\text { Öğretmenlerin, diğer öğretmenlerle işbirliği içerisinde ve koordineli olarak } \\
\text { çalışması gerekir. }\end{array}$ & 2 & .36 \\
\hline Ç20 & $\begin{array}{l}\text { Eğitim fakültesindeki seçmeli derslerin öğrenciler tarafından seçilmesi } \\
\text { gerekir. }\end{array}$ & 2 & .36 \\
\hline Ç21 & $\begin{array}{l}\text { Fen öğretmenlerinin geliştirilen öğretim programlarına göre yetiştirilmesi } \\
\text { gerekir. }\end{array}$ & 2 & .36 \\
\hline
\end{tabular}

\begin{tabular}{clrrr}
\multicolumn{1}{c}{ Kodlar } & \multicolumn{1}{c}{ Çözüm önerileri } & $\mathbf{f}$ & $\mathbf{\%}$ \\
\hline Ç22 & $\begin{array}{l}\text { Eğitim-öğretim yılı içerisinde öğretmenlerin yerlerinin } \\
\text { değiştirilmemesi gerekir. }\end{array}$ ş23 & $\begin{array}{l}\text { Öğretmenlik mesleğini yapamayanların başka mesleğe geçişinin sağlanması } \\
\text { gerekir. }\end{array}$ & 1 & .18 \\
Toplam & 563 & 100 \\
\hline
\end{tabular}

Ç: Çözüm.

\section{Ölçme-Değerlendirme ile İlgili Problemler ve Çözüm Önerileri}

$\mathrm{Bu}$ bölümde, fen bilgisi öğretmen adaylarının görüşlerine göre, ölçme-değerlendirme ile ilgili problemler tespit edilmiş (Tablo 8) ve bu problemlere yönelik çeşitli çözüm önerileri (Tablo 9) sunulmuştur.

Tablo 8.'den de anlaşılacağı gibi, ölçme-değerlendirmeyle ilgili problemlere yönelik yedi kod oluşturulmuştur. Her bir kodun kaç öğretmen tarafından ifade edildiğine dönük frekans (f) ve yüzdesi (\%) hesaplanarak Tablo 8'de sunulmuştur. Toplamda öğretmen adaylarının 2399 kere ifade ettikleri problemlerden 211 tanesi ölçme-değerlendirmeyle ilgili problemler kategorisi altında toplanmış ve tespit edilen problemlerin \% 8.8' ini $(100 \times 211=21100,21100 / 2399=8.8)$ teşkil etmiştir. Ayrıca bu kategoride yer alan her bir kodun yüzdesi 211 frekans üzerinden, örnek olarak birinci kodun yüzdesi $157 \times 100=15700$ ve 15700/211= 74.40 şeklinde, hesaplanmıştır. Fen bilgisi öğretmen adaylarını ölçmedeğerlendirmeyle ilgili problemler içerisinde en çok ifade ettikleri "Fen eğitiminde, sınav odaklı bir durumun olması ve sürekli olarak değişmesi (ilk-orta-lise ve üniversite düzeyi)" kodu \%74.40 ( $\mathrm{f}=157$ ) ile ilk sırada yer aldığı görülmüştür. Daha sonra sırasıyla, "Fen eğitiminde, yarışamaya dayalı bir değerlendirmenin ön planda olması ( $f=27, \%$ 12.79)", "Ders geçme notunun bir tehdit unsuru olarak kullanılması ( $f=11, \%$ 5.21)", "Ölçme-değerlendirmenin asıl işlevini ve fonksiyonunu yerine getirmemesi ( $f=8, \%$ 3.79)" ve "Ölçme-değerlendirmede öğrencilerin süreç içerisindeki gelişiminin dikkate alınmaması ( $f=3, \%$ 1.43)" kodlarının ölçme-değerlendirme ile ilgili problemler içerisinde yer aldığı tespit edilmiştir.

Tablo 8. Ölçme-değerlendirme ile ilgili problemler

\begin{tabular}{|c|c|c|c|}
\hline & Problemler $(\mathrm{f}=\mathbf{2 1 1}, \% \mathrm{8.8})$ & $\mathbf{f}$ & $\%$ \\
\hline Kodlar & $n=518, \sum f=2399$ & & \\
\hline P1 & $\begin{array}{l}\text { Fen eğitiminde, sınav odaklı bir durumun olması ve sürekli olarak } \\
\text { değişmesi (ilk-orta-lise ve üniversite düzeyi) }\end{array}$ & 157 & 74.40 \\
\hline $\mathrm{P} 2$ & Fen eğitiminde, yarışamaya dayalı bir değerlendirmenin ön planda olması & 27 & 12.79 \\
\hline P3 & Ders geçme notunun bir tehdit unsuru olarak kullanılması & 11 & 5.21 \\
\hline P4 & Ölçme-değerlendirmenin asıl işlevini ve fonksiyonunu yerine getirmemesi & 8 & 3.79 \\
\hline P5 & Ölçme-değerlendirmede öğrencilerin süreç içerisindeki gelişiminin dikkate & 3 & 1.43 \\
\hline
\end{tabular}


M. Diyaddin YAŞAR, Mustafa SÖZBiLiR- Çukurova Üniversitesi Eğitim Fakültesi Dergisi, 46(1), 2017, 165-201

\begin{tabular}{clccc}
\hline P6 & $\begin{array}{l}\text { alınmaması } \\
\text { Ölçme-değerlendirmede öğrenci düzeylerinin belirlenmesinin yetersiz } \\
\text { olması }\end{array}$ & 3 & 1.43 \\
P7 & Bazı üniversitelerde şartlı geçme sisteminin uygulanması & 2 & .95 \\
Toplam & & $\mathbf{2 1 1}$ & $\mathbf{1 0 0}$ \\
\hline
\end{tabular}

P: Problem.

Fen bilgisi öğretmen adaylarının görüşlerine, eğitim sisteminin daha iyi olabilmesi için ölçmedeğerlendirme problemlerine yönelik geliştirdikleri çözüm önerileri Tablo 9'da yer almaktadır. Tablo 9'dan da anlaşılacağı gibi, ölçme-değerlendirme problemlerine yönelik çözüm önerileri olarak dokuz kod oluşturulmuştur. Her bir kodun kaç öğretmen tarafından ifade edildiğine dönük frekans (f) ve yüzdesi (\%) hesaplanarak Tablo 9'da sunulmuştur. Toplamda öğretmen adaylarının 2090 kere ifade ettikleri çözüm önerilerinden 129 tanesi ölçme-değerlendirme problemlerine yönelik geliştirilen çözüm önerisi kategorisi altında toplanmış ve tespit edilen çözümlerin \% 6.17' ini (100x129=12900, 12900/2090=6.17) teşkil etmiştir. Ayrıca bu kategoride yer alan her bir kodun yüzdesi 129 frekans üzerinden, örnek olarak birinci kodun yüzdesi $47 \times 100=4700$ ve $4700 / 129=36.43$ şeklinde, hesaplanmıştır. Fen bilgisi öğretmen adaylarının ölçme-değerlendirme problemlerine yönelik geliştirdikleri çözüm önerileri sırasıyla "Fen eğitiminde, değerlendirme yapılırken öğrencilerin süreç içerisindeki gelişimleri de göz önünde bulundurulması gerekir (Etkinlik temelli, beceriye dönük, süreç odaklı değerlendirmenin ön plana

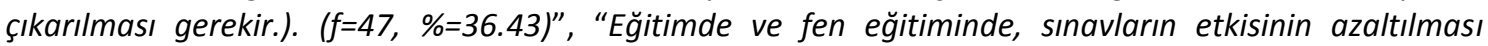
gerekir. ( $f=40, \% 31.00)$ ", "Ulusal düzeyde uygulanan sınavların (illk, orta, lise ve üniversiteye giriş sınavları vs.) bir sistematiğinin, standardın ve objektifliğinin sağlanması ve sürekli değiştirilmemesi gerekir. ( $f=28, \%$ 21.71)", "Eğitimde ve fen eğitiminde yarışmaya dayalı değil işbirliğine dönük değerlendirmelerin yaygınlaştırılması gerekir. ( $f=6, \% 4.65)$ " ve "Eğitimde, notun bir tehdit unsuru olarak kullanılmaması gerekir. ( $f=3, \% 2.33)$ " kodları ilk beşte yer aldığı saptanmıştır.

Tablo 9. Ölçme-değerlendirmeyle ilgili problemlere yönelik çözüm önerileri

\begin{tabular}{|c|c|c|c|}
\hline \multirow[b]{2}{*}{ Kodlar } & \multirow{2}{*}{\multicolumn{3}{|c|}{$\begin{array}{l}\text { Çözüm önerileri ( } f=129, \% \text { 6.17) } \\
n=518, \sum f=2090\end{array}$}} \\
\hline & & & \\
\hline Ç1 & $\begin{array}{l}\text { Fen eğitiminde, değerlendirme yapılırken öğrencilerin süreç içerisindeki } \\
\text { gelişimleri de göz önünde bulundurulması gerekir (Etkinlik temelli, beceriye } \\
\text { dönük, süreç odaklı değerlendirmenin ön plana çıkarılması gerekir.). }\end{array}$ & 47 & 36.43 \\
\hline Ç2 & Eğitimde ve fen eğitiminde, sınavların etkisinin azaltılması gerekir. & 40 & 31.00 \\
\hline Ç3 & $\begin{array}{l}\text { Ulusal düzeyde uygulanan sınavların (illk, orta, lise ve üniversiteye giriş } \\
\text { sınavları vs.) bir sistematiğinin, standardın ve objektifliğinin sağlanması ve } \\
\text { sürekli değiştirilmemesi gerekir. }\end{array}$ & 28 & 21.71 \\
\hline Ç4 & $\begin{array}{l}\text { Eğitimde ve fen eğitiminde yarışmaya dayalı değil işbirliğine dönük } \\
\text { değerlendirmelerin yaygınlaştırılması gerekir. }\end{array}$ & 6 & 4.65 \\
\hline Ç5 & Eğitimde, notun bir tehdit unsuru olarak kullanılmaması gerekir. & 3 & 2.33 \\
\hline Ç6 & $\begin{array}{l}\text { Eğitimde, ölçme-değerlendirmenin bir yaptırımı, anlamı olmalı ve gerekirse } \\
\text { sınıf tekrarı olmalıdır }\end{array}$ & 2 & 1.55 \\
\hline Ç7 & Ölçme-değerlendirmede günlük hayatla ilişkilendirme ön plana çıkarılmalıdır. & 1 & .78 \\
\hline Ç8 & Üniversitelerde şartlı geçme olmamalıdır. & 1 & .78 \\
\hline Ç9 & Üniversitelerde ders geçme notunun çok yüksek tutulmaması gerekir. & 1 & .78 \\
\hline Toplam & & 129 & 100 \\
\hline
\end{tabular}

Ç: Çözüm.

\section{Tartışma ve Öneriler}

Fen bilgisi öğretmen adaylarının görüşlerine göre elde edilen bulgularda eğitim siteminde çeşitli problemlerin olduğu saptanmıştır. Yapısal-yönetimsel problemler içerisinde, eğitim sisteminin ve öğelerinin çok sık değiştirilmesi ve mevcut siyasi gelişmelerden etkilenmesi en çok değinilen problemler arasında yer almaktadır. Nitekim Özyılmaz (2013)'inde belirttiği gibi eğitime yönelik çalışmalarda 
ideolojik yaklaşımların egemen olması eğitim sisteminin temel sorununu teşkil etmekte ve ideolojik davranan toplumların geri kaldığı aksine ideolojik davranmayıp reel-politik hareket eden toplumların ise ilerleme kaydettiği bilinmektedir. Ülkemizde de ideolojik yaklaşımların en yoğun yaşandığı alan eğitim alanıdır (Özyılmaz, 2013). Ayrıca bu çalışmada, eğitim sistemi ile ilgili yapılan değişikliklerde eğitim yöneticilerinin, öğretmenlerin, ailelerin ve öğrencilerin sürece dâhil edilmemesi ayrı bir problem olarak karşımıza çıkmaktadır. Buna ek olarak eğitimde merkezi yönetim anlayışının hâkim olması ve yapılan değişikliklerin topluma, öğretmenlere öğrencilere ve ailelere yeterli düzeyde tanıtımı ve duyurusunun yapılamaması da eğitim problemleri içerisinde yer almaktadır. Eğitime yeterli miktarda bütçenin ve ekonomik finansmanın sağlanmaması sonucunu da ayrı bir problem olarak ortaya çıkmaktadır. Bunun paralelinde, eğitim yöneticilerinin ve eğitimden sorumlu karar mercilerinin eğitim fakültesi mezunu olmaması eğitim sistemine olumsuz etki ettiği görüşü de baskın olarak karşımıza çıkmaktadır. Eğitim sisteminin etkili bir şekilde uygulanabilmesi için ülkemizin bölgesel, iller, ilçeler ve köyler arasındaki fırsat ve imkân eşitsizliklerinin olduğu ve taşımalı eğitim ile ilgili bir takım problemlerin devam ettiği sonucuna varılmıştır. Eğitim sistemi yapılandırılığında, toplumun kültürel yapısının ve bireylerin ihtiyaçlarının göz önünde bulundurulmadığı ve istihdam politikalarının eğitime çok fazla yansıtılamadığı gerçeği de fen bilgisi öğretmen adayları tarafından dile getirilmiştir. Bu çalışmadan elde edilen bulgular ile Kösterioğlu ve Bayar (2014), Özyılmaz (2013) ve Uygun (2013) yapmış oldukları çalışmalarla paralellik göstermekte; Türk eğitim sisteminde; eğitimde ideolojik davranılması ve eğitimin siyasetin etkisinde kalması, eğitimde sıkı merkeziyetçi bir yönetim anlayışının olması, eğitim bilimlerinden ve eğitim bilimcilerden yeterince yararlanılmaması, eğitim sistemimizin millileştirilememesi, eğitimde program geliştirme çalışmalarında bir sistematiğin sağlanamaması, çağdaş anlamda müfettişlik ve denetleme anlayışııı gelişmemesi, eğitimde finansman sorununun çözülememiş olması, eğitimde kamu ve özel sektörün yerinin tam olarak belirlenememiş olması vb. çeşitli sorunları tespit edilmişlerdir. Bu çalışmanın sonucunda, fen bilgisi öğretmen adayları eğitim sisteminin istenilen düzeyde uygulanabilmesi için yapısal-yönetimsel problemlere yönelik bir takım çözüm önerileri sunmuşlardır. Özellikle eğitim sisteminde yapılacak değişikliklerde belli bir alt yapı ve ön hazırlık yapılarak ihtiyaç doğrultusunda değişikliklerin ya da yeniliklerin yapılması ve çok sık değiştirilmemesi gerektiğine vurguda bulunmuşlardır. Eğitim sisteminde yapılan çok sık değişiklerin hem öğrencilerin hem de ailelerin uyum sağlamakta güçlük çektikleri sonucunu doğurmuştur. Nitekim eğitim uzun soluklu ve zahmetli bir süreçtir ve çıktıları da uzun sürmektedir. Ayrıca öğretmen adayları, tüm ülkede okul çevresi ve sınıfın fiziki koşulların düzeltilmesi, yeterli sayıda öğretmenlerin bulunması vb. gibi etkenlerin da eğitimin sağlıklı bir şekilde yürütülebilmesi için, eğitimde fırsat ve imkân eşitliğinin sağlanması, gerektiğini de belirtmişlerdir. Eğitimin bir devlet politikası haline getirilmesi, liyakat ve denetleme mekanizmasının etkili bir şekilde işlemesi de eğitimin daha sağlıklı bir şekilde yürütülmesine olanak sağlayacağı gerçeğine değinmişlerdir. Eğitim sistemine ve eğitime ayrılan bütçenin arttırıması ve adil bir şekilde dağııılması (Özyılmaz, 2013) ve bu alana artan önemin de yine hem eğitime hem de diğer alanlara olumlu etkilerinin olacağı gerçeği üzerinde durulmuştur. Ayrıca Özyılmaz (2013)'da yaptığı çalışmada eğitimde, evrensel eğitim bilimleri temel kural ve yaklaşımlarının benimsenmesi, toplumların, insanların ve eğitim sisteminin, ideolojilerin etkisinden kurtarılması, daha özgür ve daha serbest olan her bilgi ve belgeden yararlanılması gerektiği vurgulanmaktadır. Günümüz çağında artık girişimci, sorumluluk sahibi, verimli ve sürekli olarak kendini yenileyen bireylere ihtiyaç duyulmakta ve yönetimde de merkeziyetçi anlayış yerine yerinden ve yerel yönetim anlayışının geliştirilmesi gerektiği anlayışı fikri yaygınlaşmaktadır (Altan, 2014; Özyılmaz, 2013). Eğitim sistemlerinin de günümüz koşullarına göre düzenlemesi, planlanması ve organize edilmesi gerekmektedir. Bu da, daha kaliteli ve nitelikli, daha adil, yandaşığın olmadığı bir eğitim sisteminin oluşmasına yol açacaktır.

Fen bilgisi öğretmen adayları, eğitim-öğretim sürecine dönük bir takım problemlere de değinmişlerdir. En önemli problemler içerisinde, eğitim sisteminin ve fen eğitiminin hala teorik ve ezbere dayalı olarak devam ettiğine ve fiziki koşulların, araç, gereç materyallerin vb. yetersizliğine vurguda bulunmuşlardır. Eğitim sisteminde ve fen eğitiminde, öğretmen merkezli bir anlayışın olduğunu ve öğrencilerin ilgi beceri ihtiyaç ve beklentilerinin göz önünde bulundurulmadığı gerçeğini de dile getirmişlerdir. Ayrıca bu çalışmada, öğrenme-öğretme sürecinde, öğrencilerin bireysel farklılıklarının dikkate alınmadığı sonucu da ortaya çıkmıştır. Fen ve fen eğitiminin doğası gereği, laboratuar çalışmaları, 
sınıf içi ve dışı etkinlikler ağırlıkta olması, yaparak-yaşayarak öğrenme ve gerçek hayatla bağlantııı öğrenme-öğretmenin gerçekleştirilmesi gerekirken bunun eğitim öğretim sürecinde pek de sağlanamadığı görülmüştür. Bu çalışmadan elde edilen bulgular Özyılmaz (2013)'de yapmış olduğu çalışmayla paralellik göstermekte; öğrenme-öğretme sürecinin merkezinde öğretmenin olduğu, öğrencinin ise pasif bir konumda olduğu ve ezberci anlayışın hala devam ettiği belirlenmiştir. Bu anlayışın da, düşünme, sorgulama, analiz-sentez yapma, üretme, bilgiyi kullanma, problemlere yani sorunlara çözüm üretme gibi öğrenci yeteneklerinin gelişmesine engel teşkil ettiği belirtilmiştir (Özyılmaz, 2013). Bu çalışmada, fen bilgisi öğretmen adaylarının düşüncülerine göre, eğitim sisteminin ve fen eğitiminin başarıı bir şekilde ilerleyebilmesi için öğrencilerin ilgi, ihtiyaç ve beklentilerine dönük uygulamalı ve laboratuar çalışmalarına ağırık verilmesi gerektiği sonucuna varıımıştır. Öğrenci merkezli, alternatif öğretim yaklaşımlarının ve yöntemlerine ağrılık verilmesi, fiziki koşulların araç-gereç materyallerle desteklenmesi ve bilgi iletişim teknolojilerinin etkili ve yeterli bir şekilde kullanılması da eğitim sistemi ve fen eğitimine olumlu katkılar getireceği belirlenmiştir. Bu araştırmanın bulguları yine Özyılmaz (2013) yaptığı çalışmayla paralellik göstermekte; günümüz öğrenme-öğretme sürecinde, öğrenci merkezli ve çağdaş eğitim yaklaşımlarının kullanılması; teknoloji destekli ve yakın çevreyle bağlantılı olarak öğrenmenin sağlanması; öğrenci ilgi, yetenek ve ihtiyaçlarının göz önüne bulundurulması; öğrenme sorumluğuna sahip bireylerin yetiştirilmesi ve öğrenmenin gerçek yaşamla bağlantılı olarak sürdürülmesi vb. gerektiği fikri üzerinde durulmuştur. Ayrıca bu çalışmadan elde edilen bulgular Özden (2007)'nin yapmış olduğu çalışma ile de benzerlik taşımakta ve fen eğitiminde sınıfların kalabalık olduğu, yetersiz fiziki koşullar, araç-gereç materyal eksikli ve laboratuar olanaklarından çok fazla yararlanılmadığı sonucu elde edilmiştir. 21.yüzyılda eğitim sistemlerinden, öğrencilerin hem milli kültür miraslarının kendi çağlarında gerekli olan kısımlarını, hem kendi dönemlerinin bilgilerini alabilmeleri, hem de geleceklerine ışık tutacak, gelişmesine kaynaklık edecek zihinsel, bireysel ve sosyal becerileri kazandırması beklenmektedir (Özyılmaz, 2013). Ayrıca günümüz okulları, öğrenmeyi öğrenme; sorgulayııı, eleştirel ve yaratııı düşünme; çok kültürlülük ve çok dillilik; problem çözme, yaşam biçimi zenginliği ve yaşam boyu eğitim gibi hedeflere yönelmiştir (Özyılmaz, 2013). Ülkemizin de eğitim sisteminde ve öğrenme-öğretme sürecinde bu tür hedeflere yönelmesi gerektiği sonucuna varılmıştır.

Fen bilgisi öğretmen adaylarının görüşlerine göre, öğretmen eğitiminden kaynaklanan bir takım problemler de göze çarpmaktadır. Özellikle öğretmenlik niteliğine sahip olmayan fen fakültesi mezunları vb. diğer fakültelerden mezun olanların ücretli öğretmenlik, geçici öğretmenlik vb. yapması eğitim sistemini olumsuz bir şekilde etkilediği sonucuna varılmıştır. Ayrıca eğitim fakültelerinde ve fen eğitimi fakültelerinde nitelikli bir eğitimin sağlanamadığı gerçeğini de gözler önüne sermişlerdir. Eğitim fakültesine gelen öğrencilerin çok düşük puanlarla gelmesi, bu fakültelere çok sayıda öğrenci alınması, öğretmen merkezli öğretme-öğrenme faaliyetlerin baskın olması, uygulamaya dönük çalışmaların yetersizlikleri vb. buna örnek teşkil etmiştir. Ayrıca mevcut öğretmenlerin donanım ve alan bilgisi açısında yetersiz oldukları, mesleklerine gereken özveriyi göstermedikleri de saptanmıştır. Bunun paralelinde, mevcut öğretmenlere yeni yaklaşımlara dönük ve bilgi iletişim teknolojilerinin kullanımını tanıtacak yeterli düzeyde hizmet içi kurslarının düzenlenmemesi bu sorunu daha da çok derinleştirdiği belirtilmiştir. Ayrıca fen bilgisi öğretmen adayları tarafından, son yıllarda fen ve edebiyat mezunları ve diğer alanlara formasyon eğitiminin çok kısa sürede ve niteliksiz bir şekilde verilmesi ve öğretmen olma yollarının açılması da bir sorun olarak görülmüştür. Bu çalışmadan elde edilen bulgular Kösterlioğlu ve Bayar (2014) yaptıkları çalışmayla paralellik göstermekte ve öğretmen eğitimi ile ilgili ve hizmet içi eğitimine dönük çeşitli sorunların olduğunu belirtmişlerdir. Ayrıca bu çalışma, Özden (2007)'in yapmış olduğu çalışmayla da benzer sonuçlar taşımakta ve geliştirilen fen bilgisi öğretim programları hakkında fen bilgisi öğretmenlerine dönük yeterli düzeyde hizmet içi kurslarının düzenlenmediği sonucu belirlenmiştir. Bu çalışmadan elde edilen bulgulara dayalı olarak fen bilgisi öğretmen adayları öğretmen eğitimi ile ilgili problemlerin çözümüne dönük bir takım öneriler sunmuşlardır. Özellikle öğretmen eğitiminin ve eğitim fakültelerinin yeniden yapılandırılması, nitelikli öğrencilerin bu fakültelere alınması, bir takım ön koşul şartların belirlenmesi, uygulamalı ve yeni yaklaşımlara dayalı öğrenci merkezli eğitim öğretim faaliyetlerine odaklanılması vb. durumlara vurguda bulunmuşlardır. Ayrıca yeterli düzeyde öğretmen ataması yapılmalı ve ücretli, geçici öğretmenlerle eğitim-öğretimin yürütülmemesi gerektiğini belirtmişlerdir. Yine yaşı ilerlemiş, ekonomik kaygılardan dolayı öğretmenlik mesleğine devam eden 
öğretmenlerimizin emekliye ayrılması gerektiğini ifade etmişlerdir. Hem mevcut öğretmenlerimizin hem de emekli olan öğretmenlerimizin maddi ve manevi sorunları giderilmesi ve refah düzeylerini arttırılması gerektiğini belirtmişlerdir. Böylece yaşı ilerlemiş öğretmenlerimizin deneyimlerinden yararlanmak suretiyle genç ve dinamik öğretmen adaylarıın önü de açılmış olacaktır. Ayrıca hali hazırdaki öğretmenlere etkili, verimli ve uygulamalı hizmet içi kursları düzenlenmeli ve öğretmenlerin gelişimine katkı sağlanması gerektiği vurgulanmıştır. Bu çalışmadan elde edilen bulgular Özyılmaz (2013)'in yaptı̆̆ı çalışmayla paralellik göstermektedir. Yapılan bu çalışmada, öğretmen eğitiminde birtakım sorunlar ve bu sorunlara yönelik çeşitli çözüm önerilerine yer verilmiş ve bir takım öneriler sunulmuştur; öğretmen yetiştirme ve devamı olan istihdamında plan ve program eksikliğinin olduğunu ve bunun da ancak hangi branştan ne kadar öğretmene intiyaç var ise ona göre okul ve fakültelerin öğrencilerin alınmasıyla çözülebileceğini; öğretmenlik mesleğinin sadece bilen insanın bilgisini başkasına aktarmasından ibaret olmadığııı, bir sanat ve kişilik meselesi olduğunu; öğretmen yetiştiren kurumlara öğrenci hazırlayan ortaöğretim kurumlarının eğitim programlarının yetersiz olduğunu ve bu kurumların, Anadolu lisesi, meslek lisesi, öğretmen liseleri vb., öğretim programları, öğretim yöntem ve teknikleri ile eğitim araçgereçleri çağdaş verilere dayalı olarak yeniden düzenlenmesi gerektiğini; toplumda öğretmenlik mesleğinin giderek cazibesini kaybettiğini ve bu mesleğin özlük haklarında ciddi iyileştirmelerin yapılması ve sosyo-ekonomik yönden cazip hale getirilmesi gerektiğini; öğretmen yetiştirme görevi eğitim fakültelerine ait olması ve bu fakültelerin öğretim programlarının çağa uygun bir şekilde yeniden gözden geçirilmesi gerektiğini ve etkili hizmet içi kurslarının düzenlenmesi vb. gerektiğini ifade etmiştir (Özyılmaz, 2013).

Son olarak fen bilgisi öğretmen adayları eğitim sistemindeki ölçme-değerlendirme ile ilgili bir takım problemlere değinmişlerdir. Eğitim sisteminin sınav odaklı olduğunu, sürekli olarak değiştiğini ve öğrencilerin süreç içerisindeki gelişiminin dikkate alınmadığı vurgulamışlarıdır. Nitekim Özyılmaz (2013)'de belirttiği gibi eğitim sistemimizde, ölçme ve değerlendirmede öğrencilerden kendilerine öğretilen bilgilerinden ne kadarını hatırlayabildikleri ölçülmektedir. Öğrencilerin başarısı da, sınavlardan elde ettikleri yüksek nota bağlanmış bulunmaktadır. Bu da öğrencileri sosyal hayattan kopararak araştıran sorgulayan problemlere çözüm üreten bireyler olma yolunda engel teşkil ettiği sonucunu oluşturmaktadır. Yine fen bilgisi öğretmen adayları eğitimde sınavların etkisinin azaltılması, öğrenci gelişim ve ilerlemelerine dayalı ölçme-değerlendirme yaklaşımlarına ağırlık verilmesi gerektiğini belirtmişlerdir. Böylece yarışmaya dayalı olmayan iş̧irliğine dönük ölçme-değerlendirmen faaliyetlerinin, eğitim sisteminin ve fen eğitiminin, daha iyi uygulanmasına ve daha ileriye gitmesine yardımcı olacağı savunulmuştur. Nitekim Özyılmaz (2013)'de ifade ettiği gibi, ölçme ve değerlendirmede, sadece öğrenme çıktılarına odaklanılmamalı bunun yanında öğrencilerin süreç içerisindeki gelişimi de göz önünde bulundurulmalı ve etkinlik temelli, öğrencilerin öğrenme süreci esnasındaki bilgi ve becerisine dönük faaliyetlerle ölçme-değerlendirmenin sağlanması gerekmektedir. Ayrıca Altan (2014)'ın da belirttiği gibi, eğitimde sınav odaklı bir anlayışın hâkim olması öğrencilerin girişimcilik potansiyellerinin gelişmesine engel teşkil etmektedir. Bu bakımdan ülkemizde de eğitim sisteminde, ölçme-değerlendirmenin çağın gereklerine uygun olarak yapılandırılması ve uygun koşulların sağlanması gerekmektedir. 


\section{References}

Adeyinka, A. A. (1975). Current problems of educational development in Nigeria. Journal of Negro Education, 44(2), 177-188.

Ahmad, I., Rauf, M., Imdadullah \& Zeb, A. (2012). Implementation gaps in educational policies of Pakistan: Critical analysis of problems and way forward. International Journal of Humanities and Social Science, 2(21), 240-245

Altan, M. Z. (2014). Türkiye'nin eğitim çıkmazı: Girişimci öğretim-girişimci öğretmen (2.Baskı) [Turkey’s educational dilemma: Entrepreneurial teaching-enterprising teacher $\left(2^{\text {th }}\right.$ Edition)]. Ankara: Pegem Akademi

Ayas, A. (2013). Cumhuriyet döneminde Türkiye'de kimya öğretim programı geliştirme çalışmaları [Curriculum development studies in chemistry education in Turkey during Republican Era]. M. Sözbilir (Ed.), Türkiye'de kimya eğitimi [Chemistry education in Turkey] (141-153). İstanbul: Türkiye Kimya Derneği Yayınları No:22.

Barlas, D. \& Köksal, Y. (2011). Teaching a state-required course: The history of the Turkish revolution. Turkish Studies, 12(3), 525-546.

Boyer, A. \& Hamil, B. W. (2008). Problems facing American education. Focus on Colleges, Universities and Schools, 2(1), 1-9.

Büyüköztürk, Ş., Kılıç-Çakmak, E., Akgün, Ö. E., Karadeniz, Ş. \& Demirel, F. (2008). Bilimsel araştırma yöntemleri (2. Baskı) [Research methods]. Ankara: Pegem Akademi.

Cerit, Y., Akgün, N., Yıldız, K. \& Soysal, M. R. (2014). Yeni eğitim sisteminin (4+4+4) uygulanmasında yaşanan sorunlar ve çözüm önerileri (Bolu ili örneği) [Problems and solutions for the processing of the applicaiton of the new schooling system $(4+4+4)$ (City of Bolu sample)]. Eğitim Bilimleri Araştırmaları Dergisi [Journal of Educational Sciences Research], 4(1), 59-82.

Çalık, M. \&Ayas, A. (2008). A critical review of the development of the Turkish science curriculum. In R. K. Coll\& N. Taylor (Eds.) Science education in context: An international examination of context on science curricula development and implementation (p. 161-176). Rotterdam: Sense Publishers.

Demirtaş, H., Üstüner, M. \&Özer, N. (2007). Okul yönetiminde karşılaşılan sorunların öğrenci ve okul ile ilgili değişkenler açısından incelenmesi [Examining school management problems by student and school related variables]. Kuram ve Uygulamada Eğitim Yönetimi [Educational Administration: Theory and Practice], 51, 421-455.

Durmuşçelebi, M. \&Bilgili, A. (2014). Yeni (12 yıllık) eğitim sistemi, karşılaşılan sorunlar ve dünyadaki uygulamalardan bazılarının incelenmesi [The new (12 year) education system, encountered problems and its application in the World.]. Turkish Studies, 9(2), 603-621.

Erginer, A. (2009). Avrupa Birliği eğitim sistemleri: Türkiye eğitim sistemiyle karşılaştırmalar (3. Baskı) [European union education systems: a comparison with the education system in Turkey ( $3^{\text {th }}$ Edition)]. Ankara: Pegem Akademi.

Gedikoğlu, T. (2005). Avrupa birliği sürecinde Türk eğitim sistemi: sorunlar ve çözüm önerileri [Turkish education system in the process of European community: problems and solutions]. Mersin Üniversitesi Eğitim Fakültesi Dergisi [Mersin University Journal of the Faculty of Education], 1(1), 6680.

Gömleksiz, M.,N. \& Kan, A.Ü. (2007). Yeni ilköğretim programlarının dayandığı temel ilke ve yaklaşımlar [Basic principles and approaches of new primary school curricula]. Doğu Anadolu Bölgeleri Araştırmaları [East Anatolia Region Researches], 5(2), 60-66.

Grossmann, G. M., Onkol, P. E. \& Sands, M. (2007). Curriculum reform in Turkish teacher education: Attitudes of teacher educators towards change in an EU candidate nation. International Journal of Educational Development, 27, 138-150.

Keser, Ö. F. (2005). Recommendations towards developing educational standards to improve science education in Turkey. The Turkish Online Journal of Educational Technology, 4(1), 46-53.

Kösterioğlu, İ. \& Bayar, A. (2014). Türk eğitim sisteminin sorunlarına ilişkin güncel bir değerlendirme [A recent evaluation of the problems of the Turkish education system]. The Journal of Academic Social Science Studies, 25(1), 177-178. 
McMillan, J. H. \& Schumacher, S. (2010). Research in education: Evidence-based inquiry (7 $7^{\text {th }}$ Edition). Boston: Pearson Education.

Memon, G. R. (2007). Education in Pakistan: The key issues, problems and the new challenges. Journal of Management and Social Sciences, 3(1), 47-55.

MoNE (Minister of National Education) (2005). Talim ve Terbiye Kurulu Başkanlığı, Ilköğretim Fen ve Teknoloji dersi (4. ve 5.sınıflar) öğretim programı [Science and Technology Curriculum grade 4 and 5]. Ankara: Devlet Kitapları Müdürlüğü.

MoNE (Minister of National Education) (2006). Talim ve Terbiye Kurulu Başkanlığı, Ilköğretim Fen ve Teknoloji dersi (6. 7. ve 8.sınıflar) öğretim programı [Science and Technology Curriculum grade 6.,7 and 8.]. Ankara: Devlet Kitapları Müdürlüğü.

MoNE (Minister of National Education) (2007). Talim ve Terbiye Kurulu Başkanlığı Ortaöğretim Kimya dersi 9.sınıf öğretim programı (9 grade chemistry curriculum). Ankara: Devlet Kitapları Müdürlüğü.

MoNE (Minister of National Education) (2013). Ortaöğretim kimya dersi (9,10,11 ve12.sınıflar) öğretim programı (Secondary school chemistry curriculum grade 9,10,11 and 12). Ankara: MEB Yayınları.

Odia, L. O. \& Omofonmwan, S. I. (2007). Educational system in Nigeria: Problems and prospects. KamlaRaj Journal of the Social Sciences, 14(1), 81-86.

Özden, M. (2007). Problems with science and technology education in Turkey. Eurasia Journal of Mathematics, Science \& Technology Education, 3(2), 157-161.

Özyılmaz, Ö. (2013). Türk milli eğitim sisteminin sorunları ve çözüm arayışları (4. Baskı) [Problems of the Turkish national education system and search for solutions]. Ankara: Pegem Akademi.

Rashid, K. Mukhtar, S. (2012). Education in Pakistan: Problems and their solutions. International Journal of Academic Research in Business and Social Sciences, 2(11), 332-343.

Sözbilir, M., Kutu, H. \&Yaşar, (2012). Science education research in Turkey: A content analysis of selected features of published papers. D. Jorde and J. Dillon (Eds.). Science education research and practice in Europe: Retrospective and Prospective (341-374). Netherlands: Sence Publishers.

Sutherland, M. B. (1982). Progress and problems in education in Northern Ireland, 1952-1982. British Journal of Educational Studies, 1, 136-149.

Şişman, M. (2012). Türk eğitim sistemi ve okul yönetimi (6. Baskı) [Turkish education system and school management]. Ankara: Pegem Yayıncılık.

Türkmen, L. \& Bonnstetter, R. J. (2007). Influences of some philosophical approaches in the historical development of Turkish science education. Science Education International, 18(1). 139-151.

Udey, F. U., Ebuara, V. O., Ekpoh, U. I. \& Edet, A. O. (2009). Management and administration of Nigerian education system: Problems, challenges, and the way forward. Paper presented at the $11^{\text {th }}$ International Conference of Educational Management Association of South Africa (EMASA) 7-9 August, $2009 \quad$ Pretoria / South Africa.[Online] http://www.emasa.co.za/files/emasa2009/21_EMASA2009 Udey.pdf, retrieved December, 08, 2015.

Uygun, S. (2013). Türk eğitim sistemi sorunları (Geleneksel ve güncel) (1. Baskı) [Problems of Turkish education system (traditional and contemporary)]. Ankara: Nobel Akademik Yayıncılık.

Yeşil, R. \& Şahan, E. (2015). Öğretmen adaylarının Türk eğitim sisteminin en önemli sorun, neden ve çözüm yollarına ilişkin algıları [Perceptions of teacher candidates about the most important problem of Turkish education system, its reasons and its solutions]. Ahi Evran Üniversitesi Kırşehir Eğitim Fakültesi Dergisi [Journal of Ahi Evran University Kırşehir Education Faculty], 16(3), 123-143.

Yıldırım, A. \& Şimsek, H. (2008). Sosyal bilimlerde nitel araştırma yöntemleri (7. Baskı) [Qualitative research methods in the social sciences $\left(7^{\text {th }}\right.$ edition)]. Ankara: Seçkin Yayıncılık.

Yılmaz, K. \& Altınkurt, Y. (2011). Öğretmen adaylarınınTürk eğitim sisteminin sorunlarına ilişkin görüşleri [Prospective teachers' views about the problems of Turkish educational system]. Uluslararası insan Bilimleri Dergisi [International Journal of Human Sciences], 8(1), 943-973. 